University of Nebraska - Lincoln

DigitalCommons@University of Nebraska - Lincoln

Faculty Publications in Food Science and Technology

Food Science and Technology Department

8-20-2002

\title{
Discovering lactic acid bacteria by genomics
}

Todd Klaenhammer

Southeast Dairy Foods Research Center, North Carolina State University, klaenhammer@ncsu.edu

Eric Altermann

Southeast Dairy Foods Research Center, North Carolina State University, Raleigh, NC

Fabrizio Arigoni

Nestle Research Center, Vers-chez-les-Blanc, 1000 Lausanne 26, Switzerland

Alexander Bolotin

Genetique Microbienne, CRJ INRA, Domaine de Vilvert, 78352 Jouy en Josas cedex, France

Fred Breidt

USDA Agricultural Research Service

See next page for additional authors

Follow this and additional works at: https://digitalcommons.unl.edu/foodsciefacpub

Part of the Food Science Commons

Klaenhammer, Todd; Altermann, Eric; Arigoni, Fabrizio; Bolotin, Alexander; Breidt, Fred; Broadbent, Jeffrey; Cano, Raul; Chaillou, Stephane; Deutscher, Josef; Gasson, Mike; van de Gutche, Maarten; Guzzo, Jean; Hartke, Axel; Hawkins, Trevor; Hols, Pascal; Hutkins, Robert W.; Kleerebezem, Michiel; Kok, Jan; Kuipers, Oscar; Lubbers, Mark; Maguin, Emanuelle; McKay, Larry; Mills, David; Nauta, Arjen; Overbeek, Ross; Pel, Herman; Pridmore, David; Saier, Milton; van Sinderen, Douwe; Sorokin, Alexei; Steele, James; O'Sullivan, Daniel; de Vos, Willem; Weimer, Bart; Zagorec, Monique; and Seizen, Roland, "Discovering lactic acid bacteria by genomics" (2002). Faculty Publications in Food Science and Technology. 20.

https://digitalcommons.unl.edu/foodsciefacpub/20

This Article is brought to you for free and open access by the Food Science and Technology Department at DigitalCommons@University of Nebraska - Lincoln. It has been accepted for inclusion in Faculty Publications in Food Science and Technology by an authorized administrator of DigitalCommons@University of Nebraska Lincoln. 


\section{Authors}

Todd Klaenhammer, Eric Altermann, Fabrizio Arigoni, Alexander Bolotin, Fred Breidt, Jeffrey Broadbent, Raul Cano, Stephane Chaillou, Josef Deutscher, Mike Gasson, Maarten van de Gutche, Jean Guzzo, Axel Hartke, Trevor Hawkins, Pascal Hols, Robert W. Hutkins, Michiel Kleerebezem, Jan Kok, Oscar Kuipers, Mark Lubbers, Emanuelle Maguin, Larry McKay, David Mills, Arjen Nauta, Ross Overbeek, Herman Pel, David Pridmore, Milton Saier, Douwe van Sinderen, Alexei Sorokin, James Steele, Daniel O'Sullivan, Willem de Vos, Bart Weimer, Monique Zagorec, and Roland Seizen 


\title{
Discovering lactic acid bacteria by genomics
}

Todd Klaenhammer ${ }^{1, *}$, Eric Altermann ${ }^{1}$, Fabrizio Arigoni ${ }^{3}$, Alexander Bolotin ${ }^{4}$, Fred Breidt $^{5}$, Jeffrey Broadbent ${ }^{6}$, Raul Cano ${ }^{7}$, Stephane Chaillou ${ }^{24}$, Josef Deutscher ${ }^{8}$, Mike Gasson ${ }^{9}$, Maarten van de Guchte ${ }^{4}$, Jean Guzzo ${ }^{10}$, Axel Hartke ${ }^{25}$, Trevor Hawkins ${ }^{11}$, Pascal Hols ${ }^{12}$, Robert Hutkins ${ }^{13}$, Michiel Kleerebezem ${ }^{2}$, Jan Kok $^{14}$, Oscar Kuipers ${ }^{14}$, Mark Lubbers ${ }^{15}$, Emmanuelle Maguin ${ }^{4}$, Larry McKay ${ }^{16}$, David Mills ${ }^{17}$, Arjen Nauta ${ }^{18}$, Ross Overbeek ${ }^{19}$, Herman $\mathrm{Pel}^{20}$, David Pridmore ${ }^{3}$, Milton Saier ${ }^{21}$, Douwe van Sinderen ${ }^{22}$, Alexei Sorokin ${ }^{4}$, James Steele $^{23}$, Daniel O'Sullivan ${ }^{16}$, Willem de $\operatorname{Vos}^{2}$, Bart Weimer ${ }^{6}$, Monique Zagorec ${ }^{24}$ \& Roland Siezen $^{2,26, *}$

${ }^{1}$ Department of Food Science, Southeast Dairy Foods Research Center, North Carolina State University, Raleigh, NC 27695-7624, USA; ${ }^{2}$ Wageningen Center for Food Sciences, 6700AN Wageningen, The Netherlands; ${ }^{3}$ Nestlé Research Center, Vers-chez-les-Blanc, 1000 Lausanne 26, Switzerland; ${ }^{4}$ Génétique Microbienne, CRJ INRA, Domaine de Vilvert, 78352 Jouy en Josas cedex, France; ${ }^{5}$ USDA Agricultural Research Service, Department of Food Science, North Carolina State University, Raleigh, NC 27695-7624, USA; ${ }^{6}$ Department of Nutrition and Food Sciences, Utah State University, Logan, UT 84322-8700, USA; ${ }^{7}$ Environmental Biotechnology Institute, California Polytechnic State University, San Luis Obispo, CA 93407, USA; ${ }^{8}$ Laboratoire de Génétique des Microorganismes, INRA-CNRS URA1925, F-78850 Thiverval-Grignon, France; ${ }^{9}$ Institute of Food Research, Norwich, UK, ${ }^{10}$ Laboratoire de Microbiologie, UMR INRA-Université de Bourgogne, Equipe PG2MA ENSBANA 21000 Dijon, France; ${ }^{11}$ Joint Genome Institute Production Genomic Facility, 2800 Mitchell Drive, Walnut Creek, CA 94598, USA; ${ }^{12}$ Unité de Génétique, Batiment Camoy, Place Croix du Sud, UCL, B-1348, Louvain-la Neuve, Belgium; ${ }^{13}$ University of Nebraska, Department of Food Science and Technology, Lincoln, NE 68583-0919, USA;

${ }^{14}$ Department of Molecular Genetics, University of Groningen, 9751NN Haren, The Netherlands; ${ }^{15}$ Fonterra Research Centre [Formerly the New Zealand Dairy Research Institute], Private Bag 11 029, Palmerston North, New Zealand; ${ }^{16}$ Department of Food Science and Nutrition,University of Minnesota, St. Paul, MN 55108, USA; ${ }^{17}$ Department of Viticulture and Enology, University of California, Davis, CA 95616-8749, USA; ${ }^{18}$ Corporate Research FCDF, PO Box 87, 7400AB Deventer, The Netherlands; ${ }^{19}$ Interegated Genomics Inc, 2201W Campbell Park Dr, Chicago, IL 600612, USA; ${ }^{20}$ DSM Food Specialties, PO Box 1, 2600MA Delft, The Netherlands; ${ }^{21}$ University California, San Diego, La Jolla, CA 92093-0116, USA; ${ }^{22}$ Department of Microbiology, University College Cork, Cork, Republic of Ireland; ${ }^{23}$ Department of Food Science, University of Wisconsin-Madison, Madison, WI 53706-1565, USA; ${ }^{24}$ Flore Lactique et Environnement Carné, INRA-CRJ, Domaine de Vilvert, 78350 Jouy-enJosas, France, ${ }^{25}$ Laboratoire de Microbiologie de l'Environnement, EA 956 USC INRA, IRBA Université de Caen, F-14032 Caen Cedex, France; ${ }^{26}$ Center for Molecular and Biomolecular Informatics, University of Nijmegen, PO Box 9010,6500GL Nijmegen, The Netherlands (*Authors for correspondence; E-mail: klaenhammer@ncsu.edu, siezen@cmbi.kun.nl)

Key words: lactic acid bacteria, genomics, Gram-positive bacteria, food, health, Lactococcus, Lactobacillus, Streptococcus, Pediococcus, Leuconostoc, Oenococcus, Propionibacterium, Bifidobacterium, Brevibacterium

\begin{abstract}
This review summarizes a collection of lactic acid bacteria that are now undergoing genomic sequencing and analysis. Summaries are presented on twenty different species, with each overview discussing the organisms fundamental and practical significance, environmental habitat, and its role in fermentation, bioprocessing, or probiotics. For those projects where genome sequence data were available by March 2002, summaries include
\end{abstract}


a listing of key statistics and interesting genomic features. These efforts will revolutionize our molecular view of Gram-positive bacteria, as up to 15 genomes from the low GC content lactic acid bacteria are expected to be available in the public domain by the end of 2003. Our collective view of the lactic acid bacteria will be fundamentally changed as we rediscover the relationships and capabilities of these organisms through genomics.

\section{Introduction (contributed by Todd Klaenhammer)}

The lactic acid bacteria (LAB) represent a group of bacteria that are functionally related by their ability to produce lactic acid during homo- or heterofermentative metabolism. The acidification and enzymatic processes accompanying the growth of LAB impart the key flavor, texture, and preservative qualities to a variety of fermented foods. Industrial applications of the LAB rely on six key beneficial and nonpathogenic species; Lactococcus (milk), Lactobacillus (milk, meat, vegetables, cereal), Leuconostoc (vegetables, milk), Pediococcus (vegetables, meat), Oenococcus oeni (wine) and Streptococcus thermophilus (milk). Other members of the LAB, notably lactobacilli, occupy important niches in the gastrointestinal tracts of humans and animals and are considered to offer a number of probiotic benefits to general health and well being. These benefits include a positive influence on the normal microflora, competitive exclusion of pathogens, and stimulation/modulation of mucosal immunity. More recently, LAB are being used in the production of industrial chemical and biological products including biopolymers (Leuconostoc spp.), bulk enzymes (Lactobacillus brevis), ethanol, and lactic acid (Lactobacillus casei, lactis, delbrueckii, brevis) (Gold et al. 1992; Hofvendahl \& Hahn-Hagerdal 2000). The LAB are also strong candidates for development as oral delivery vehicles for digestive enzymes and vaccine antigens (Wells et al. 1996; Pouwels et al. 1998; Steidler et al. 2000). Their innate acid tolerance, ability to survive gastric passage, and safety record during human consumption, are key features that can be exploited to effectively deliver biologics to targeted locations and tissues.

Realizing their practical significance in fermentation, bioprocessing, agriculture, food, and more recently, medicine, the $\mathrm{LAB}$ have been the subject of considerable research and commercial development over the past decade. Contributing to this explosion have been the recent efforts to determine the genome sequences of a representative collection of LAB species and strains. The first complete genome of the LAB group was published on Lactococcus lactis subsp. lactis IL1403 by Bolotin et al. (2001). The genome was
$2.4 \mathrm{Mb}$ in size and revealed a number of unexpected findings: biosynthetic pathways for all 20 amino acids, albeit not all are functional, a complete set of late competence genes, five complete prophages, and partial components for aerobic metabolism. Noting that some of these systems are not functional or complete, the genomic analysis of Lactococcus suggests an evolutionary trend toward minimization of the chromosome and elimination of unnecessary systems during adaptation to nutritionally complex environments, such as milk. At this writing, four other LAB genomes have been completed, (L. plantarum, L. johnsonii, L. acidophilus, S. thermophilus), and $>20$ more are in progress (Table 1) with expected completions for sequencing by the end of 2002. Additional genome sequencing is underway for microbes that are not considered as members of the LAB, but contribute important LABlike properties either as probiotics (Bifidobacterium longum, B. breve, and Brevibacterium linens) or flavor adjuncts (B. linens, Propionibacterium freudenreichii). Among the total genome projects ongoing, there are several cases where genome sequences will become available for multiple strains of the same species, notably L. lactis (three strains), L. casei (two strains), L. delbrueckii (three strains), S. thermophilus (three strains), Oenococcus oeni (two strains) and $B$. longum (two strains).

Of the 29 genomes listed in Table 1 on LABtype microbes, 11 genomes are being sequenced by the Department of Energy-Joint Genome Institute (JGI) in collaboration with the Lactic Acid Bacteria Genome Consortium (LABGC), composed of 10 US scientists representing seven universities in the U.S. As part of their microbial genomes program (see http://www.jgi.doe.gov/JGI_microbial/ $\mathrm{html} /$ index.html) JGI will carry out genome sequencing of LAB species representing considerable diversity in ecological habitat (milk, meat, plants, GI tract) and roles (probiotic versus fermentation). All of the microbial genomes will undergo the same processing; first to generate a $10 \times$ coverage of each genome with a random shotgun small-insert library $(3 \mathrm{~kb})$, and to supplement this with $\sim 5 \times$ coverage of a large insert $(40 \mathrm{~kb})$ cosmid library. These data will be incorporated into an assembly and the assembled scaffolds 
Table 1. Genome sequencing projects of lactic acid bacteria

\begin{tabular}{|c|c|c|c|c|}
\hline Species & Strain & $\begin{array}{c}\text { genome } \\
\text { size }(\mathrm{Mb})\end{array}$ & Contact person & Institution \\
\hline \multicolumn{5}{|l|}{ Sequencing completed } \\
\hline Lactococcus lactis & IL1403 & 2.3 & A. Sorokin & INRA and Genoscope, FR \\
\hline Lactobacillus plantarum & WCFS1 & 3.3 & M. Kleerebezem & WCFS, NL \\
\hline Lactobacillus johnsonii & NCC533 & 2.0 & D.Pridmore & Nestlé, CH \\
\hline Lactobacillus acidophilus & $\begin{array}{l}\text { ATCC700396 } \\
\text { NCFM }\end{array}$ & 2.0 & T. Klaenhammer, R. Cano & $\begin{array}{l}\text { North Carolina State University and Cal- } \\
\text { Poly Technical University, USA }\end{array}$ \\
\hline Bifidobacterium longum & NCC2705 & 2.3 & F. Arigoni & Nestlé, $\mathrm{CH}$ \\
\hline \multicolumn{5}{|l|}{ Sequencing ongoing } \\
\hline $\begin{array}{l}\text { Lactococcus lactis } \\
\text { ssp. cremoris }\end{array}$ & MG1363 & 2.6 & $\begin{array}{l}\text { O.Kuipers, M.Gasson, } \\
\text { D. van Sinderen }\end{array}$ & $\begin{array}{l}\text { University of Groningen, NL; IFR, UK; } \\
\text { UCC, IRL }\end{array}$ \\
\hline $\begin{array}{l}\text { Lactococcus lactis } \\
\text { ssp. cremoris }\end{array}$ & MG1363 & 2.4 & A. Sorokin, A. Bolotin & INRA, FR \\
\hline $\begin{array}{l}\text { Lactobacillus delbrueckii } \\
\text { ssp. bulgaricus }\end{array}$ & ATCC11842 & 2.3 & E. Maguin, M.vd Guchte & Genoscope and INRA, FR. \\
\hline $\begin{array}{l}\text { Lactobacillus delbrueckii } \\
\text { ssp. bulgaricus }\end{array}$ & DN-100107 & 2.1 & T. Smokvina & Danone Vitapole, FR \\
\hline Lactobacillus sakei & $23 \mathrm{~K}$ & 1.9 & M. Zagorec, S. Chaillou & INRA, FR. \\
\hline Lactobacillus casei & BL23 & 2.6 & J. Deutscher, A. Hartke & INRA/CNRS, Caen University, FR \\
\hline Lactobacillus helveticus & CNRZ32 & 2.4 & J. Steele & University of Wisconsin, USA \\
\hline Lactobacillus rhamnosus & HN001 & 2.4 & M. Lubbers & $\begin{array}{l}\text { Fonterra Research Center (formerly NZDRI) } \\
\text { and ViaLactia BioSciences, NZ }\end{array}$ \\
\hline Streptococcus thermophilus. & LMG18311 & 1.9 & P. Hols & UCL, Belgium \\
\hline Streptococcus thermophilus & CNRZ1066 & 1.8 & A.Bolotin & INRA, FR, Integrated Genomics Inc, USA \\
\hline Oenococcus oeni & IOEB84.13 & 1.8 & J. Guzzo & $\begin{array}{l}\text { Universities Dijon and Bordeaux-INRA- } \\
\text { GENOME Express, FR }\end{array}$ \\
\hline Bifidobacterium breve. & NCIMB8807 & 2.4 & D. van Sinderen & University College Cork (UCC), IRL \\
\hline $\begin{array}{l}\text { Propionibacterium } \\
\text { freudenreichii }\end{array}$ & ATCC6207 & 2.6 & H. Pel, J. Sikkema & $\begin{array}{l}\text { DSM Food Specialties, Friesland Coberco } \\
\text { Dairy Foods, NL }\end{array}$ \\
\hline \multicolumn{5}{|c|}{ Joint Genome Institute/Lactic Acid Bacteria Genome Consortium (JGI/LABGC) } \\
\hline Lactobacillus gasseri & ATCC33323 & 1.8 & T. Klaenhammer & North Carolina State University, USA \\
\hline Lactobacillus casei & ATCC334 & $>2.2$ & J. Broadbent & Utah State University, USA \\
\hline $\begin{array}{l}\text { Lactobacillus delbrueckii } \\
\text { ssp. bulgaricus }\end{array}$ & ATCCBAA-365 & 2.3 & J. Steele & University of Wisconsin, Madison, USA \\
\hline Lactobacillus brevis & ATCC367 & 2.0 & M. Saier & University of California, San Diego, USA \\
\hline $\begin{array}{l}\text { Lactococcus lactis } \\
\text { ssp. cremoris }\end{array}$ & SK11 & 2.3 & B. Weimer, L. McKay & $\begin{array}{l}\text { Utah State University and University of } \\
\text { Minnesota, USA }\end{array}$ \\
\hline Leuconostoc mesenteroides & ATCC 8293 & & F. Breidt, H.P. Fleming & $\begin{array}{l}\text { USDA, North Carolina State University, } \\
\text { USA }\end{array}$ \\
\hline Oenococcus oeni & $\begin{array}{c}\text { PSU1 } \\
\text { ATCC BAA-331 }\end{array}$ & 1.8 & D. Mills & University of California, Davis, USA \\
\hline Pediococcus pentosaceus & ATCC25745 & 2.0 & J. Steele, J. Broadbent & $\begin{array}{l}\text { University of Wisconsin, Madison, Utah } \\
\text { State University, USA }\end{array}$ \\
\hline Streptococcus thermophilus & ATCC BAA-491 & 1.8 & R. Hutkins & University of Nebraska, USA \\
\hline Brevibacterium linens & BL2/ ATCC 9174 & 3.0 & B. Weimer & Utah State University, USA \\
\hline Bifidobacterium longum & DJ010A & 2.1 & D. O'Sullivan & University of Minnesota, USA \\
\hline
\end{tabular}


ordered by PCR primer walking to fill gaps. The scaffolds will undergo an automated annotation which will be performed by Oak Ridge National Laboratories.

It is noteworthy that as these sequences are generated, they will be placed in the public domain on the JGI website for common use. The timely and public availability of genome information for various $\mathrm{LAB}$ species will catapult our collective efforts to carry on with comparative and functional genomic analyses of the LAB group.

The explosion of available genome sequences for LAB will accelerate their exploitation in both traditional and non-traditional arenas. While phylogenetically closely related by their small genomes $(\sim 2-4$ $\mathrm{Mb}$ ), the LAB occupy a diverse set of ecological niches suggesting that considerable genetic adaptation has occurred during their evolution. Comparison of the genome sequences of multiple LAB species and strains is expected to provide a critical view of microbial adaptation and genetic events leading to their adaptation to specialized environments. Comparative genomics among the microbes sequenced thus far has already illustrated that essential housekeeping gene functions are widely conserved among microbes and horizontal gene transfer commonly occurs. An expected outcome of comparative genomics of LAB will be the definition of conserved and unique genetic functions in LAB that enable core functions, e.g., production of lactic acid, proteolytic and peptidase activities, survival at low $\mathrm{pH}$, stress tolerance, production of antimicrobials, transport systems, cell signaling, and attachment/retention in dynamically mobile environments.

It is anticipated that IS-elements, bacteriophages, and mobile genetic elements provide the major routes through which horizontal gene transfer occurs, and the roadmap to the most interesting and practically significant genetic regions that underscore the unique and beneficial properties of the LAB. It is well documented that the LAB undergo conjugation, exist in phagecontaminated environments where gene transfer may occur by transduction, and harbor sets or remnants of competence genes for transformation (Bolotin et al. 2001). Understanding gene transfer, particularly in environments where LAB coexist, or compete, will provide one important view of their evolution, adaptation, and potential for unique applications. Conjugation has played a key role in the evolution and adaptation of L. lactis to a milk environment noting that many attributes for growth in milk, including lactose and casein utilization and bacteriophage res- istance, are encoded by conjugative plasmid DNA in this species (Broadbent 2001).

With the availability of genomic maps of more than $25 \mathrm{LAB}$, comparative genomic analysis will identify critical similarities and differences and is expected to identify 'islands of adaptability', defined as key genetic regions that may be instrumental in the evolution of the various species to their specialized habitats, and their functions within those environments. Comparisons of food-grade LAB with other related Grampositive pathogens (Enterococcus faecalis, Streptococcus agalactiae, Streptococcus equi, Streptococcus pneumoniae, Streptococcus mutans, Streptococcus pyogenes, Listeria monocytogenes) has already revealed many common features and will most certainly define the essential genetic differences between pathogens, non-pathogens, and commensals. Over the next year, our scientific community will be fundamentally empowered by the availability of numerous related, yet distinct genomes, to make these comparative analyses and define the similarities and differences that characterize the genomes of LAB.

This chapter presents a collection of summaries on the LAB organisms that are now in genomic sequencing or analysis. Each summary describes the organism and its roles in the environment or bioprocessing, the status of the sequencing effort as of March 2002 and, for some, selected interesting features that have been uncovered (Tables 2 and 3). Our view of the LAB will be fundamentally changed as we discover the relationships and capabilities of these organisms through genomics.

\section{SUMMARIES OF SEQUENCING PROJECTS}

\section{Lactococcus lactis subsp. cremoris SK11 (contributed by Larry L. McKay and Bart Weimer)}

Lactococci are mesophilic LAB that were first isolated from green plants. However, today they are used extensively in food fermentations, which represent about $20 \%$ of the total economic value of fermented foods produced throughout the world. This group of bacteria, previously designated the lactic streptococci (Streptococcus lactis subsp. lactis or S. lactis subsp. cremoris) was placed in this new taxon in 1987 by Schleifer. Lactococci gained notable interest because many of their functions important for successful fermentations are linked to plasmid DNA 


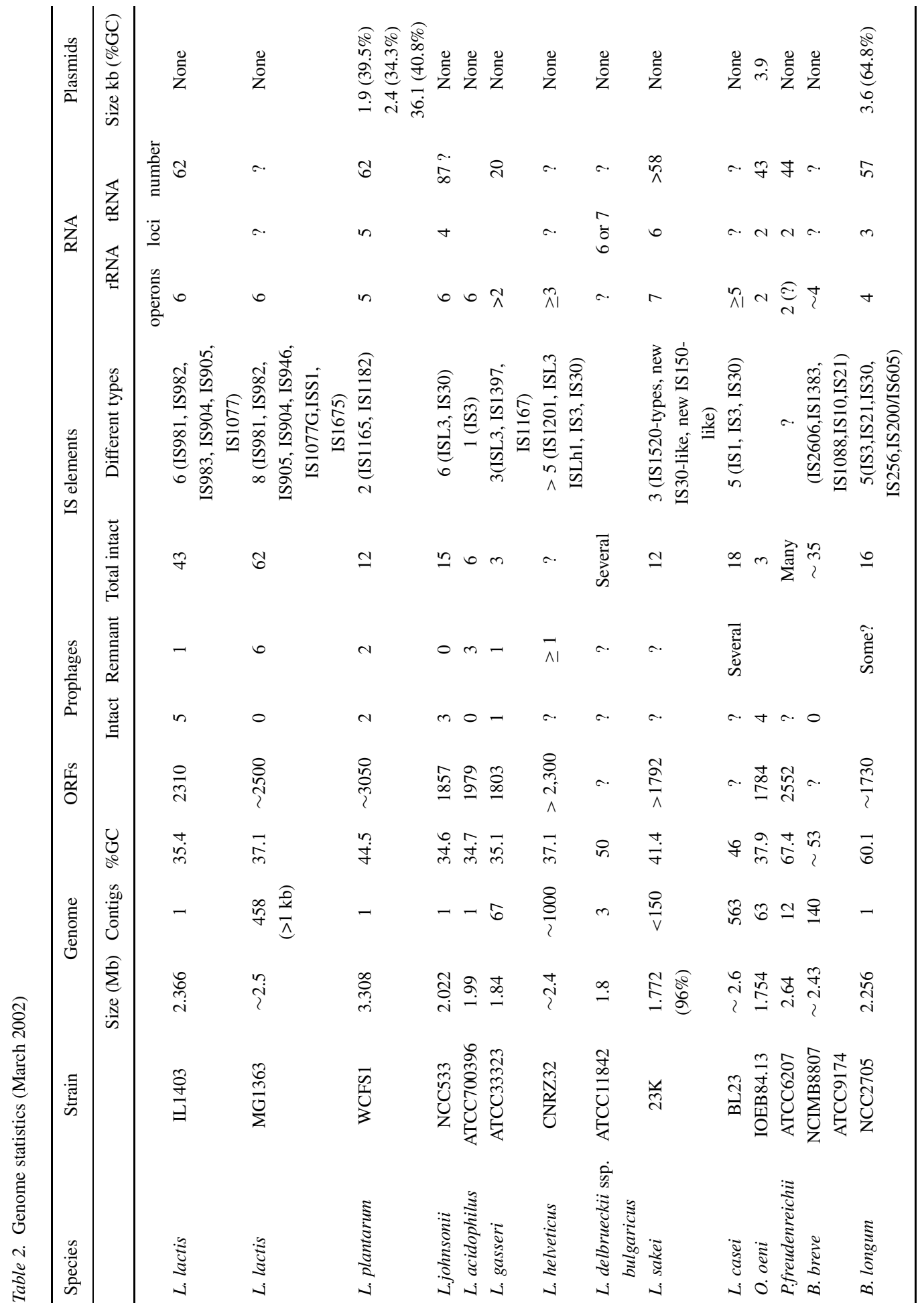




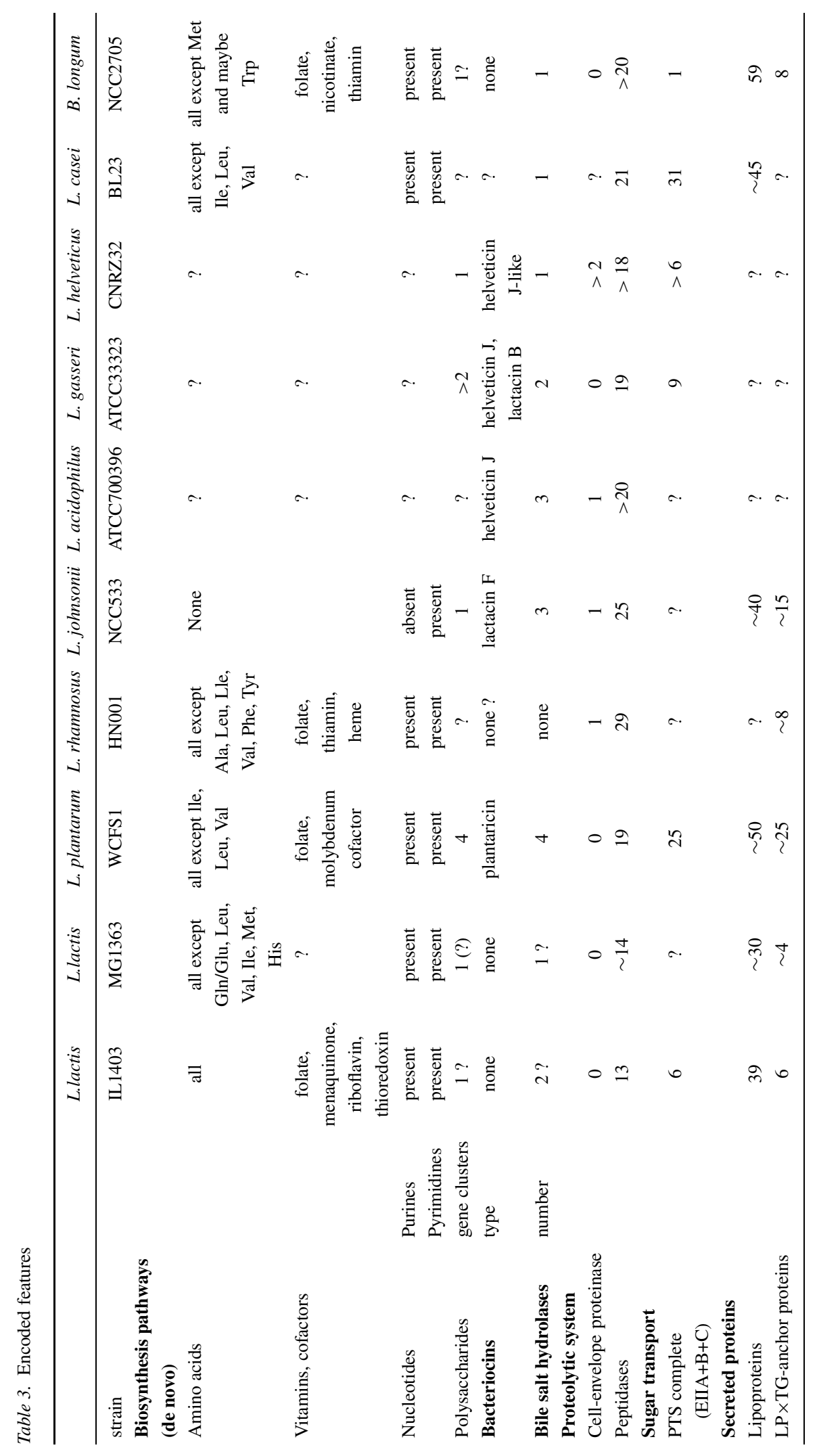


(McKay 1985). Plasmids are commonly exchanged between strains via conjugation (McKay 1985; Dunny $\&$ McKay 1999) and with the chromosome by IS elements (Hughes 2000). Presumably, these exchanges and rearrangements mediate rapid strain adaptation and evolution but also add to the instability of important metabolic functions.

These bacteria are selected for use in fermentations based on their metabolic stability, their resistance to bacteriophage, and their ability to produce unique compounds - often from amino acid catabolism. The study of their physiology in adverse conditions such as low $\mathrm{pH}$ and high $\mathrm{NaCl}$ indicates that they adapt to these environments quickly and change their metabolism as a result of carbohydrate starvation (Stuart \& Weimer 1998). Recent genome studies and physical maps indicate that bacterial genomes are very dynamic (Hughes 2000). These rearrangements are mediated by IS elements and result in gene duplication, translocation, inversion, deletion and horizontal transfer events. For example, an inversion encompassing approximately one-half of the chromosome of L. lactis ML3 occurred by homologous recombination between two copies of IS905 (Daveran-Mingot et al. 1998). The response to these stresses, particularly to exposure to bacteriophage (Forde \& Fitzgerald 1999), highlights the plasticity of the genome (Le Bourgeois et al. 1995; Delorme et al. 1994; Davidson et al. 1996). Establishing the links between environmental conditions, genome organization, and cellular physiology in lactococci will provide new and exciting information about the molecular mechanisms of these important bacteria. Advances that define the fundamental knowledge of the genetics, molecular biology, physiology, and biochemistry of lactococci will provide new insights and applications for these bacteria.

The importance of lactococci, specifically L. lactis subsp. cremoris, is demonstrated by its continual use in food fermentations (Garvie et al. 1981; Beimfohr et al. 1997). L. lactis subsp. cremoris strains are preferred over L. lactis subsp. lactis strains because of their superior contribution to product flavor via unique metabolic mechanisms (Sandine, 1988; Salama et al. 1991). The DNA sequence divergence between the subspecies is estimated to be between 20 and 30\% (Godon et al. 1992). Of the many lactococcal strains used, L. lactis subsp. cremoris SK11 is recognized for the beneficial flavor compounds it produces (Lawrence et al. 1976). Although some progress in unlocking this strain's genetic secrets has been made, much more can be accomplished by using a genomics/proteomics ap- proach. With this genome sequence, it will be possible to confirm the metabolic and evolutionary differences between subspecies of lactococci in order to identify the important characteristics that define this genus.

\section{Acknowledgments}

The Joint Genome Institute of the US Department of Energy is supporting the sequencing effort for this LAB genome. The efforts of K. Baldwin, L.-S. Chou, Y. Xie, T. Hawkins, S. Stilwagen, P. Richardson, and K. Kadner are gratefully acknowledged.

\section{Lactococcus lactis ssp. cremoris MG1363 (contributed by Douwe van Sinderen, Mike Gasson, Jan Kok and Oscar Kuipers)}

Lactococcus lactis ssp. cremoris MG1363 is a cured isolate of strain NCDO 712 (Gasson, 1983), and is the most widely used model Lactococcus strain in genetic, physiological and applied research all over the world. L. lactis is a prominent bacterium in cheese production and can also be used for various other applications such as a vehicle for oral vaccines or delivery of health-promoting factors via the GI tract. Even before the genome sequencing projects started already over $10 \%$ of its gene content had been identified and characterized by conventional methods. Recently the complete genome sequence of $L$. lactis ssp. lactis IL1403 was published (Bolotin et al. 2001), providing a great opportunity to compare the two genomes, with respect to their similarities and differences. Many important features, such as pathways leading to the formation of flavour compounds, carbon and nitrogen metabolic routes, gene regulation mechanisms, prophage or sex-factor occurrence, and stress responses can be compared when the genome sequence of MG1363 is also known. Functional studies using transcriptome and proteome analyses can also be applied in order to speed up characterisation of important novel targets.

\section{Genome sequencing status and results}

To obtain the complete nucleotide sequence of the genome of Lactococcus lactis subsp. cremoris MG1363 a shotgun sequencing approach was used. The sequence of 15000 ends of inserts of pUC clones, ranging in size from 1 to $3 \mathrm{~kb}$, have been determined, yielding 9 million bp of sequence. The obtained 
sequences were aligned with known sequences of MG1363 present in the NCBI nucleotide database ( \pm $270 \mathrm{~kb}$ ) and sequences present within the consortium $( \pm 150 \mathrm{~kb})$ using the Staden and Sequencer software packages. As the construction of a random library with inserts larger than $20 \mathrm{~kb}$ failed, the genome sequence of L. lactis subsp. lactis IL1403 was used as a template to start completing the genome sequence. After positioning of all the contigs on IL1403, forward and reverse primers were designed using an in-house developed software tool, in the ends of the contigs. The nucleotide sequences of the PCR fragments are currently being used to close the gaps. Annotation of the nucleotide sequence is being done with Glimmer, Blast, PFAM, Blocks.

\section{Acknowledgments}

We thank Sinead Leahy, Gerald Fitzgerald, Udo Wegmann, Claire Shearman, Girbe Buist, Richard Baerends, Aldert Zomer, Sacha van Hijum, and Anne de Jong for their contributions and support.

\section{Lactococcus lactis ssp. cremoris MG1363 (contributed by Alexei Sorokin and Alexander Bolotin)}

Two strains, IL1403 and MG1363, isolated from industrial sources and cured from plasmids, are commonly used to study genetics, physiology and molecular biology of Lactococcus lactis. These strains belong to two L. lactis strain clusters, called lactis and cremoris, distinct by the spectra of dairy fermentation products. We sequenced the entire genome of the strain IL1403 (Bolotin et al. 1999, 2001). To compare genomes of the two strains in the simplest way we decided to perform a co-linear scaffolding of the chromosome of strain MG1363. Co-linear scaffolding consists in random sequencing of a limited number of clones and Long Range PCR mapping of the co-linear regions of two genomes, one of which was completely sequenced earlier. In the co-linear regions, established by PCR, gene content and order should be approximately the same. The established co-linear scaffold of the MG1363 genome, which shares $85 \%$ identity with that of IL1403, allows easy access to 50\% of the genes from this strain.

\section{Genome sequencing status and results}

Total DNA of L. lactis MG1363 was randomized by $A l u \mathrm{I}$ in conditions of non-complete digestion or by sonication and extracted after separation in an $0.8 \%$ agarose gel to give an average fragment size of $1.5 \mathrm{~kb}$. It was then cloned into vector pSGMU2 cut by SmaI and the inserts from approx. 1500 random clones were sequenced by forward and reverse primers. Sequences of 513 of these clones, having a total non-redundant length of $0.3 \mathrm{Mb}$, were used to construct a co-linear scaffold of the strain MG1363 over IL1403. The total size of the co-linear genome parts was estimated to be around $1100 \mathrm{~kb}$, that is approximately $45 \%$ of the entire genome (Bolotin et al. 2002). Oligonucleotidedirected sequencing over gaps amplified by LR PCR fragments of MG1363 and the entire sequence of a few regions of interest resulted in the accumulation of $1038 \mathrm{~kb}$ non-redundant sequence distributed in 733 contigs. The contigs were compared for homology, using BLASTx, with the complete protein set of L. lactis IL1403. Sequences of 523 contigs encode proteins that are more than $80 \%$ identical to proteins from IL1403. The sequences of the 733 contigs are available from GenBank as dbGSS (acc. Nos. BH770319-BH771051).

\section{Acknowledgments}

We thank Saulius Kulakauskas for giving us the $L$. lactis ssp cremoris MG1363 strain, Nathalie Galleron and Benois Quinquis for assisting in bank constructions and sequencing. Discussions with members of Lactococcus communities of Génetique Microbienne and UPLGA labs (CRJ INRA) and their interest to this work are very appreciated.

\section{Lactobacillus plantarum WCFS1 (contributed by Michiel Kleerebezem and Roland Siezen)}

The genus Lactobacillus encompasses a large number of different species that display a relatively large degree of diversity. Among these, Lactobacillus plantarum is a flexible and versatile species that is encountered in a large variety of environmental niches, including some dairy, and many vegetable or plant fermentations. Some strains of Lactobacillus are found as natural commensals of the gastrointestinal tract (GI tract), the oral cavity and the female uro-genital tract 
of animals and humans. The ability to adhere to specific regions of the GI tract is a property which has stimulated research aimed at the use of lactobacilli as delivery-vehicles for therapeutic compounds such as immunomodulators, antibodies, enzymes and vaccines (Marteau \& Rambaud 1993 Hols et al. 1997; Slos et al. 1998). Lactobacillus plantarum arrives in the small intestine in an active state (Vesa et al. 2000) and is frequently encountered as a natural inhabitant of the human gastro-intestinal tract (Ahrne et al. 1998). Some strains are being marketed as probiotic. Previous studies using gel electrophoresis have indicated that $L$. plantarum has one of the largest genomes known among lactic acid bacteria (Chevalier et al. 1994; Daniel 1995). The Wageningen Centre for Food Sciences (WCFS) in collaboration with Greenomics in Wageningen, has determined the complete genome sequence of $L$. plantarum WCFS1, a single colony isolate of strain NCIMB8826, a strain of human origin.

\section{Genome sequencing status and results}

Sequencing was accomplished using a shotgun approach, while $\lambda$-clones and multiplex PCR were used to fill the gaps. The circular chromosome of $L$. plantarum WCFS1 consists of $3308274 \mathrm{bp}$ with an average $\mathrm{G}+\mathrm{C}$ content of $44.5 \%$, and is among the largest of lactic acid bacteria. In addition, the strain harbours three plasmids of $36069 \mathrm{bp}(\mathrm{G}+\mathrm{C}$ content: 40.8\%), 2365 bp (G+C content: $34.3 \%$ ), and $1917 \mathrm{bp}$ ( $\mathrm{G}+\mathrm{C}$ content: $39.5 \%)$, respectively. Automated prediction software (Glimmer, Genemark) was used to obtain a primary prediction of protein encoding genes, which was manually improved to result in a current list containing about 3050 genes.

The orientation of the majority of the genes is highly organized from the origin to the terminus of replication for both halves of the chromosome. Five rRNA-encoding operons, with very few sequence polymorphisms, could be identified scattered around the chromosome. Automated ORF analysis and functional annotation was performed using BioScout (LION) and Pedant-Pro (BioMax) software packages, followed by extensive manual curation. Functions were predicted for over $65 \%$ of the gene products. Major categories are proteins involved in energy metabolism (8\%), cell envelope (8\%), transport (13\%) and regulation (9\%). Over 2300 encoded proteins have expect scores better than 1e-10 to database entries, and nearly $90 \%$ of these are most similar to proteins of other Gram-positive bacteria, predom- inantly those encoded in the genomes of Listeria, Lactococcus, Bacillus and Streptococcus.

L. plantarum is a versatile and flexible organism and is able to grow on a wide variety of sugar sources. This phenotypic trait is reflected by the high number of predicted PEP-dependent sugar phosphotransferase systems (PTS; 25 complete) and other sugar transporters encoded by WCFS1. Strikingly, over $60 \%$ of these sugar transporters are located within $250 \mathrm{~kb}$ in both directions from the origin of replication.

\section{Acknowledgments}

We thank Jos Boekhorst, Bjorn Ursing, Richard van Kranenburg, Douwe Molenaar and Willem de Vos for their contribution to this work. Sequencing and assembly were performed by Greenomics (www.greenomics.com).

\section{Lactobacillus rhamnosus HN001 (contributed by James Dekker and Mark Lubbers)}

Lactobacillus rhamnosus is one of the few species of Lactobacillus that have been used as probiotic organisms in functional foods. In addition, this species is one of the two most common non-starter lactic acid bacteria found in New Zealand cheddar cheese; the other is $L$. paracasei. We have identified a strain of $L$. rhamnosus, designated HNO01, that has both flavourenhancing and probiotic attributes. It can be used as an adjunct during cheese manufacture to reduce adventitious microflora, accelerate cheese ripening, and improve cheese flavour. We have also demonstrated that HN001 has the 'prerequisite' properties of a probiotic, including confirmation of taxonomic classification, acid and bile resistance, adherance to intestinal cells, transient colonisation, and lack of any toxicity or detrimental effects (Prasad et al. 1998; Zhou et al. 2000a,b, 2001; Gopal et al. 2001; Sheih et al. 2001). A number of in vitro and in vivo tests, including and human clinical trials, have demonstrated the ability of HNO01 to influence specific cytokines, NK cell activity, T cell stimulatory capacity and phagocytic ability, and influence the balance of the intestinal microflora in humans (Gill et al. 2000, 2001a; Tannock et al. 2000). HN001 also has antimicrobial activity against important gut pathogens (Gill et al. 2001b). L. rhamnosus HN001 is genetically accessible and we have developed tools and techniques for efficient gene disruption and overexpression. Therefore, HNO01 is an ideal candidate for 
an in-depth study of factors that contribute to probiotic and flavour-enhancing attributes of lactobacilli.

\section{Genome sequencing status and results}

A draft genome sequence of HNOO1 was obtained by shotgun sequencing. Analysis of the data indicates a genome size of about $2.4 \mathrm{Mb}$, and an average $\mathrm{G}+\mathrm{C}$ content of approximately $46.4 \%$, which is within the range reported for other $L b$. rhamnosus species. In addition, HN001 harbours two plasmids of $8754 \mathrm{bp}$ (G+C content: $41.9 \%$ ) and approximately $40000 \mathrm{bp}$ ( $\mathrm{G}+\mathrm{C}$ content: $43.7 \%$ ). Automated ORF prediction and annotation were not used. Rather, the whole genome sequence was compared against publicly available databases and the output manually examined for genes of specific interest. In addition, metabolic pathways of particular interest were also identified. To date, over 900 candidate genes have been examined and almost 300 genes with potential involvement in flavour, survival and probiotic activity (e.g. gut adhesion, immune and anti-microbial activity) have been identified. Of these, 39 HN001 genes have been functionally characterised using a number of approaches, including gene knockout by disruption, overexpression, gene complementation and biochemical assay of purified recombinant protein.

\section{Acknowledgments}

We acknowledge the valuable contributes of Michael Collett, Christopher Pillidge, and Marie-Laure Delabre, and the financial support of our sponsors $\mathrm{Vi}$ aLactia BioSciences NZ Ltd, the New Zealand Foundation for Research Science and Technology, and the Marsden Fund of the Royal Society of New Zealand.

\section{Lactobacillus johnsonii La1 (NCC2761) (contributed by David Pridmore)}

Lactobacillus johnsonii strains have been mainly isolated from the feces of humans and animals (Johnson et al. 1980; Fujisawa et al. 1992), suggesting that these bacteria constitute part of the natural intestinal flora. L. johnsonii La1 (formerly Lactobacillus acidophilus La1) is a Nestlé proprietary strain that has been extensively studied for its probiotic properties and is commercialised in the $\mathrm{LC}^{1}$ fermented milk products. La1 shows immunomodulatory properties (Link-Amster et al. 1994; Schiffrin et al. 1995; Haller et al. 2000a,b), antipathogenic properties (Bernet et al. 1994; BernetCamard et al. 1997; Felley et al. 2001; Pérez et al. 2001) and the ability to interact with the host (Granato et al. 1999; Neeser et al. 2000). The determination and analysis of the complete genome sequence of $L$. johnsonii La1 has provided valuable targets for the investigation of the above interactions. L. johnsonii La1 is amenable to genetic manipulation, an important consideration in view of the wealth of information revealed in the genome sequence and the interest to investigate the probiotic features of this bacterium at the genetic level. Efficient transformation by plasmids, the ability to use $\mathrm{pG}+$ host 9 and its temperature sensitive replication to produce genetic disruption of selected genes and the application of pG+host9:ISS1 (Maguin et al. 1996) to produce random mutations are some of the tools available, making $L$. johnsonii La1 an important host for advanced genetic analysis.

\section{Genome sequencing status and results}

Random shotgun cloning and sequencing was supplemented with sequencing of BAC clones and longrange PCR products to finally produce a circular chromosome of approximately $2.022 \mathrm{Mbp}$. The computerpredicted SmaI digest closely matches the physical digest pattern. Bioinformatic analysis has identified the L. johnsonii La1 counterparts of the best-studied genes and pathways. The initial analysis of these results has not revealed any major surprises, except for the complete lack of amino acid biosynthetic pathways which appears to be compensated for by an increased number of amino acid transporters. Given the limited literature describing the natural habitat of this bacterium, a more profound analysis of the genetic potential of $L$. johnsonii La1 could provide important clues as to the nutritional composition of its environment. The structure of the L. johnsonii La1 chromosome is unusual in that both the plot of GC skew and the direction of the transcription of the majority of genes do not place the proposed terminus opposite the origin (approximately $1000 \mathrm{~kb}$ ), but close to $1300 \mathrm{~kb}$. This chromosome structure may be explained by the structure, orientation and position of two genes encoding large cell-wall anchored proteins in $L$. johnsonii Lal. Both genes predict proteins with more than 100 copies of a conserved 10 amino acid repeat. This repeat is reflected in the gene sequences and may be the target for recombination. Inversion of the approximately $600 \mathrm{~kb}$ of sequence between the repeat would position 
the terminus opposite the origin. A second example of $L$. johnsonii La1 genome rearrangement has been observed by defining the direct repeats produced by IS element transposition. One pair of elements showed a perfect exchange of the direct repeat sequences. Confirmed by PCR, this event has produced an inversion of approximately $800 \mathrm{~kb}$ of the L. johnsonii La1 genome. Extension of this analysis to other L. johnsonii isolates has allowed the identification of some of the intermediates in the events leading to the $L$. johnsonii La1 genome configuration.

\section{Acknowledgments}

Anne-Cecile Pittet, Marie-Camille Zwahlen, Bernard Berger, Mark Schell, David Vilanova, Maria Karmirantzou, Frank Desiere and Josef Hermanns are sincerely thanked for their contribution to this work.

\section{Lactobacillus acidophilus ATCC700396 / NCFM (contributed by Todd R. Klaenhammer and Raul Cano)}

In 1900, Moro first isolated Lactobacillus acidophilus from infant feces. Meaning 'acid loving', acidophilus can be found in the intestinal tract of humans and animals, as well as infants consuming high milk, lactose, or dextran diets. Metchnikoff's 1906 work on The prolongation of life: optimistic studies, implicated a lactic acid bacillus, found in Bulgarian yoghurts, as the agent responsible for deterring intestinal putrefaction and aging. Later, Lactobacillus acidophilus was considered to be the most likely species to fulfill the base criteria expected of a probiotic cultures; survival through the GI tract, bile tolerance, acid tolerance, and antimicrobial production. Over the last century a considerable amount of research has been carried out on L. acidophilus, and a group of closely-related species clustered in a group known as the 'acidophilus complex' (Klaenhammer \& Russell, 1999). Of the six species in the group, L. acidophilus continues to be the bacterium most often implicated in providing probiotic benefits and remains to be the species most commonly found in foods or supplements that contain probiotic cultures. In a recent survey, Clark et al. (2001) found that when L. acidophilus was recovered from probiotics samples, the majority of confirmed strains showed a genetic fingerprint resembling that of NCFM. The L. acidophilus NCFM culture has been used commercially since 1972 in a variety of products and probiotic dairy foods, like Sweet Acidophilus ${ }^{T M}$ milk. Its long history of safe use in commercial products for and human consumption, and its close genetic relationship to the neotype strain, ATCC4356 (Walker et al. 1996), were two major reasons that the L. acidophilus NCFM strain (deposited as ATCC700396) was selected for genome sequencing.

L. acidophilus is an obligate homofermenter and metabolizes hexoses primarily to lactic acid. Both the D- and L-isomers of lactate are produced. L. acidophilus NCFM metabolizes fructo-oligosaccharides (Kaplin \& Hutkins 2000), which are prebiotic compounds that support the growth of beneficial gut bacterial. Some of the functional properties of this organism have been reviewed (Sanders \& Klaenhammer 2001) and include: survival through the GI tract (Conway et al. 1982), reduction of fecal mutagenic enzymes (Goldin \& Gorbach 1980; Goldin et al. 1980), adherence to intestinal tissues (Conway et al. 1987; Greene \& Klaenhammer 1994), stimulation of IgA in mice by a culture cocktail that includes $L$. acidophilus NCFM (Tejada-Simon \& Pestka 1999), and production of the bacteriocin, lactacin B (Barefoot \& Klaenhammer 1983). In contrast to the other members of the acidophilus complex, there is considerable information on L. acidophilus NCFM related to its transformability by electroporation (Luchansky et al. 1988; Walker et al. 1996) and the development of genetic tools, that will be used for the functional genomic analysis of this species (Kullen \& Klaenhammer 1999; Russell \& Klaenhammer 2001a,b).

\section{Genome sequencing status and results}

Genome sequencing was accomplished using a shotgun random library approach and pUC18. PCR and direct genome sequencing (Fidelity Systems, Inc.) were used to fill gaps and polish selected regions. The genome has been assembled into a single contig and consists of $1.99 \mathrm{Mbp}$ with an average GC content of $34.6 \%$. The genome was automatically annotated by the prediction, database, and annotation software GAMOLA (Global annotation of multiplexed on-site blasted DNA sequences) to identify 1979 ORFs in a coding density of $89.9 \%$. Predicted ORFs were manually verified against the on-site Blast and Pfam databases. Some features encoded in the NCFM genome are six copies of an IS3-type element, two bacteriocins, three distinct regions encoding competence genes, two $l d h$ 
genes, two bile salt hydrolase genes, two operons for fructo-oligosaccharide (FOS) utilization, and no intact prophages. There is also a collection of genome sequence information available in public databases for various strains of the L. acidophilus species, including heat shock operons groELS and dnaK, a sigma factor ropD, bacteriocins acidocins 8912 and $\mathrm{B}$, bile salt hydrolase, and $\beta$ - and phospho- $\beta$-galactosidases. Comparison of the NCFM genome sequence with these available database sequences has revealed a number of interesting similarities and marked differences.

\section{Acknowledgments}

This project was supported by Dairy Management, Inc, the Southeast Dairy Foods Research Center, the California Dairy Foods Research Center, the Environmental Biotechnology Institute and Rhodia, Inc. The efforts of Eric Altermann, Mike Russell, A. Hamrick, T. Cox, and D. Doherty are gratefully acknowledged.

\section{Lactobacillus gasseri ATCC33323, neotype (contributed by Todd R. Klaenhammer, Eric Altermann and Rodolphe Barrangou)}

Recent developments in molecular taxonomy have revealed six different Lactobacillus species that comprise the 'acidophilus' group, which are widely considered as model probiotic organisms (Klaenhammer \& Russell 2000). Among these, Lactobacillus gasseri appears to represent the major homofermentative Lactobacillus species that occupies the human GI tract (Mitsuoka, 1992; Kullen et al. 2000; Heilig et al. 2002). L. gasseri demonstrates good survival in the GI tract (Conway et al. 1982; Pedrosa et al. 1995) and has been associated with a variety of probiotic activities and roles including reduction of fecal mutagenic enzymes (Pedrosa et al. 1995), adherence to intestinal tissues (Conway et al. 1987; Greene \& Klaenhammer 1994), stimulation of macrophages (Kitazawa et al. 1994; Kirjavainen et al. 1999; Kitazawa et al. 1994), and production of bacteriocins (Itoh et al. 1995).

Data are available on the transformability by electroporation (Russell \& Klaenhammer 2001a,b), and expression of heterologous genes in L. gasseri (Cho et al. 2000), as well as on the genome sequence of one of its temperate bacteriophage (Altermann et al. 1999). L. gasseri is more amenable to DNA introduction and manipulation than other members of the acidophilus complex, leading to the development of genetic tools that will be essential to functional genomic analysis of this species (Kullen \& Klaenhammer 1999; Russell \& Klaenhammer 2001a,b).

\section{Genome sequencing status and results}

Genome sequencing of the L. gasseri neotype strain, ATCC 33323, was carried out by the Department of Energy-Joint Genome Institute in collaboration with the Lactic Acid Bacterial Genomics Consortium. The strategy for genome sequencing was based on a shotgun random sequencing of a small genomic DNA insert (average $2.5 \mathrm{~kb}$ ) library cloned into pUC18 at approximately 8 -fold coverage, complimented by sequencing a large insert (35-45 kb) Fosmid library at a lower coverage. Gap closing is ongoing using a multiplex PCR approach. The genome assembly of $L$. gasseri currently consists of 67 contigs, representing a total of $1.84 \mathrm{Mbp}$, with an average $\mathrm{G}+\mathrm{C}$ content of $35.1 \%$. The sequence information is posted on the JGI Microbial Genomes web site at: (http://www.jgi.doe.gov/JGI_microbial/html/ lactobacillus_gas/lactob_gas_homepage.html) GAMOLA ( $G$ lobal Annotation of $O$ n-site $B$ asted DNA-sequences) software was developed by E. Altermann to automatically predict coding open reading frames (ORFs) and annotate the draft sequence (http://www.cals.ncsu.edu/ food_science/trk/main.html). GAMOLA relies on the available software Glimmer2 (Delcher et al. 1999), NCBI toolkit (National Center for Biotechnology Information Bldg 38A, NIH 8600 Rockville Pike Bethesda, MD 20894), Primer3 (Rozen \& Skaletsky, 1997) and HMMER2.2g (Eddy 1998) and combines the results into functionally annotated DNA sequences in Genbank format.

For the L. gasseri sequence, the automated annotation predicted 1803 ORFs larger than $100 \mathrm{bp}$. The average gene length is $930 \mathrm{bp}$ with a coding percentage of $89.1 \%$. After the initial automated annotation, the genome was predicted to encode: 31 $\mathrm{ABC}$ transporters, 14 ion-ATPase transporters and two proton-antiporters; 21 PTS-systems (some partial), 16 stress responsive genes (sigma factor, chaperones, heat shock operons and chaperones), one intact prophage, 14 mobile elements (transposases, integrases and ISelements), 32 genes involved in cell-cycle or cellshape, eight genes implied in aggregation/adhesion, seven genes related to late competence, 40 peptidases (proteolytic system plus general peptidases), 20 tRNA genes, and at least two rRNA operons. Manual curation of the automated annotation will be carried out 
upon completion of genome sequencing and closure of the major gaps.

This project has revealed a number of gene systems that are likely to be important in the gastrointestinal survival and activity of this human probiotic species. The public availability of the L. gasseri genome will promote comparative genomic analysis among LAB.

\section{Acknowledgment}

The Joint Genome Institute of the US Department of Energy and the Lactic Acid Bacteria Genome Consortium is supporting this sequencing project. The efforts of R. Barrangou, E. Altermann, W. M. Russell, T. Hawkins, S. Stilwagen, P. Richardson, and K. Kadner are gratefully acknowledged. Additional support was provided by Dairy Management, Inc, the Southeast Dairy Foods Research Center and Rhodia, Inc.

\section{Lactobacillus helveticus CNRZ32 (contributed by: Jim Steele and Jeff Broadbent)}

Within the genus Lactobacillus, L. helveticus is part of the obligately homofermentative ('Group I') cluster, which can produce D- and L-lactic acid from hexose sugars via the Embden-Meyerhof pathway and is incapable of fermenting pentoses (Axelsson 1998). L. helveticus grows on a relatively restricted number of carbohydrates that includes lactose and galactose and typically requires riboflavin, pantothenic acid and pyridoxal for growth (Hammes \& Vogel 1995).

Phylogenetically, L. helveticus is quite closely related $(<10 \%$ sequence divergence) to L. amylovorus, L. acidophilus, L. delbrueckii, L. acetotolerans, L. gasseri, and L. amylophilus. Among these species, L. helveticus is most closely related $(<2 \%$ sequence divergence) to L. amylovorus and L. acidophilus (Schleifer \& Ludwig 1995). The genome size of $L$. helveticus has been determined to be $2.4 \mathrm{Mb}$ by pulse-field gel electrophoresis (unpublished data). Approximately 40 chromosomal genes and four plasmids have been sequenced from L. helveticus. Methods for electroporation and gene replacement have been developed for L. helveticus CNRZ32 (Bhowmik \& Steele 1993; Bhowmik et al. 1993); however, attempts to utilize these methods with other strains of L. helveticus have been unsuccessful.

L. helveticus is a component of 'thermophilic' starter cultures used in the manufacture of a number of fermented dairy products (Hassan \& Frank, 2001).
These cultures have an optimum growth temperature of approximately $42^{\circ} \mathrm{C}$ and contain Streptococcus thermophilus with L. delbrueckii subsp. bulgaricus and/or L. helveticus. These cultures are utilized in the manufacture of Swiss-type and Italian-type cheese varieties. There has been a $325 \%$ increase in the past 20 years in the production of Mozzarella cheese in the United States to more than 2244 million pounds, with an economic value of nearly $\$ 1$ billion (National Cheese Institute 1998). Additionally, strains of L. helveticus are commonly used as flavor adjunct cultures, where they are added to bacterial ripened cheese varieties to reduce bitterness and accelerate the development of beneficial flavors.

To have utility in the manufacture of fermented dairy products strains must be resistant to bacteriophage, have stable fermentation properties, and consistently produce products with acceptable flavor and texture attributes. A significant body of research is available concerning the proteolytic system of these organisms, with at least 15 components of the proteolytic system characterized at the nucleotide level and numerous single and double mutants lacking specific components studied in detail (Christensen et al. 1999). Limited information is available concerning a number of other industrially relevant metabolic pathways (i.e., carbohydrate fermentation) and enzymes (i.e., esterases). Genomic sequence analysis of $L$. helveticus will allow researchers to fill the significant gaps present in our understanding of the physiology of this organism by providing a comprehensive view of the enzymes and metabolic pathways potentially involved in industrially relevant phenotypes. This knowledge will allow researchers to develop more effective strategies to enhance the utility of these organisms in the manufacture Swiss-type and Italian-type cheese varieties as well as their utility as flavor adjunct cultures.

\section{Acknowledgment}

This project was supported by Dairy Management, Inc. through the Wisconsin Center for Dairy Research and the Western Dairy Center, College of Agricultural and Life Sciences and Chr. Hansen, Inc. Fred Blattner and George F. Mayhew from the Genome Center of Wisconsin are thanked for their assistance with genome assembly and annotation. 


\section{Lactobacillus delbrueckii subsp. bulgaricus ATCC BAA-365 (contributed by James Steele)}

Within the genus Lactobacillus, L. delbrueckii is part of the obligately homofermentative ('Group I') cluster, which can produce D-lactic acid from hexose sugars via the Embden-Meyerhof pathway and is incapable of fermenting pentoses (Axelsson 1998). The $L$. delbrueckii species contains three subspecies, L. delbrueckii subsp. delbrueckii, L. delbrueckii subsp. lactis, and L. delbrueckii subsp. bulgaricus. $L$. delbrueckii subsp. bulgaricus grows on a relatively restricted number of carbohydrates and typically requires pantothenic acid and niacin (Hammes \& Vogel 1995).

Phylogenetically, L. delbrueckii subsp. bulgaricus is closely related ( $<10 \%$ sequence divergence) to $L$. amylovorus, L. acidophilus, L. helveticus, L. acetotolerans, L. gasseri, and L. amylophilus (Schleifer \& Ludwig 1995). The GC ratio of L. delbrueckii subsp. bulgaricus $(49-51 \%)$ is somewhat higher than that found among other species (34-46\%) within this phylogenetic tree (Hammes \& Vogel 1995). The genome size of L. delbrueckii subsp. bulgaricus has been determined to be $2.3 \mathrm{Mb}$ by pulse-field gel electrophoresis (Leong-Morgenthaler 1990). Very few chromosomal genes $(<15)$ have been sequenced from $L$. delbrueckii subsp. bulgaricus, however the complete sequence of a small cryptic plasmid and the partial sequence of a bacteriophage are known. Gene transfer systems for L. delbrueckii subsp. bulgaricus include two conjugation-based gene transfer systems (Rantsiou et al. 1999; Thompson et al. 1999) and electroporation (Serror et al. 2002).

L. delbrueckii subsp. bulgaricus is a component of 'thermophillic' starter cultures used in the manufacture of a number of fermented dairy products (Hassan \& Frank 2001). These cultures have an optimum growth temperature of approximately $42{ }^{\circ} \mathrm{C}$ and contain Streptococcus thermophilus with L. delbrueckii subsp. bulgaricus and/or L. helveticus. These cultures are utilized in the yogurt, Swiss-type and Italian-type cheese varieties. There has been a $240 \%$ increase in the past 20 years in the production of yogurt in the United States to 1371 million pounds in 1997, with a wholesale value of over $\$ 1.1$ billion (Milk Industry Foundation 1998).

\section{Acknowledgments}

The Joint Genome Institute of the US Department of Energy is supporting the sequencing effort for this LAB genome. The efforts of T. Hawkins, S. Stilwagen, P. Richardson, and K. Kadner are gratefully acknowledged.

\section{Lactobacillus delbrueckii ssp. bulgaricus ATCC11842 \\ (contributed by Maarten van de Guchte and Emanuelle Maguin)}

Lactobacillus delbrueckii ssp. bulgaricus is a thermophilic lactic acid bacterium that is principally known for its use in yogurt production, where it assures milk fermentation in conjunction with Streptococcus thermophilus. As such, L. bulgaricus is one of the economically most important LAB.

For the type strain ATCC11842 a reproducible transformation procedure is available (Serror et al. 2002) as well as gene inactivation systems (unpublished) that will allow the exploitation of genome data. A Proteome reference map has been established (unpublished) which will facilitate and benefit from a genome analysis. In this context, the determination of the complete genome sequence of this strain was undertaken in a joint effort of the Centre National de Séquençage (CNS, Genoscope, Evry Fr) and the Institut National de la Recherche Agronomique (INRA).

\section{Genome sequencing}

Although the genome size of $L$. bulgaricus was previously estimated to be $2.3 \mathrm{Mbp}$, recent pulse field electrophoresis analysis revealed that the genome size of the type strain ATCC11842 was about 1.8 Mbp. The genome sequence has been determined using a shotgun sequencing approach. Contigs were assembled after sequencing of two plasmid libraries with differently sized inserts. Sequences from a mini-BAC library were subsequently used for scaffolding. The scaffold structure was validated by long range PCR, and links between the initial scaffolds were established by multiplex long accurate PCR. The average GC content of the L. bulgaricus genome is $50 \%$, while regions that presumably result from horizontal transfer can be detected with GC contents as low as $31 \%$. 


\section{Acknowledgments}

We thank V. Barbe, S. Oztas, S. Mangenot, C. Robert, R. Eckenberg, R. Dervyn, A-M. Dudez, M. Zagorec, J. Weissenbach, and S.D. Ehrlich for their contribution and support. We thank Alexei Sorokin and Alexander Bolotin for helpful discussions.

\section{Lactobacillus sakei 23K (contributed by Stéphane Chaillou and Monique Zagorec)}

Lactobacillus sakei is the predominant LAB found on fresh meat and is widely used as starter in fermented meat products in Western Europe. It is also occasionally found on silage, sourdough and smoked fish. The physiology of L. sakei is still poorly understood when compared to dairy LAB. Recent studies seem to indicate that $L$. sakei has developed original metabolic and physiological traits to adapt to a meat environment (for a review see Champomier-Verges et al. 2002). To better understand the ability and fitness of L. sakei to grow on meat we have chosen the genomic approach. The $L$. sakei genome sequencing project was launched in year 2000 , using strain $23 \mathrm{~K}$, isolated from sausage, as a model.

\section{Genome sequencing status and results}

A physical and genetic mapping of the chromosome was first established by pulse-field gel electrophoresis after digestion with rare-cutting enzymes (Dudez et al. 2002). This preliminary map allowed to estimate the chromosome size to be about $1.85 \mathrm{Mb}$. Seven rrn operons including one doublet were identified and their flanking regions characterised. The sequencing of $90 \%$ of the genome was accomplished by a classical shotgun strategy, where 8000 clones were first sequenced on their forward side, followed by reads on the reverse side for 2000 clones flanking contigs end, and 500 internal reads. The gap closure phase was carried out using ligation-mediated PCR and several customised BLAST strategies against related genomes such as Bacillus subtilis, Bacillus halodurans and Listeria monocytogenes. Remaining gaps are currently analysed with a set of other strategies such as multiplex PCR, sequencing on chromosomal DNA, and contigs ordering based on the physical map. Currently, $96 \%$ of the genome has been sequenced with an average base redundancy of $4 \times$. A preliminary analysis of the genome content was carried out with the CDS prediction software SHOW (Nicolas et al. 2002) revealing 1792 putative protein-encoding genes for $1772 \mathrm{kp}$ sequenced. Automated annotation followed by manual curation will be done with a improved version of Artemis software from the Sanger Center, UK.

\section{Acknowledgments}

This project was financed by the Institut National de la Recherche Agronomique (INRA).

\section{Lactobacillus casei ATCC 334 (contributed by Jeffrey Broadbent)}

Lactobacillus casei are rod-shaped LAB with a G + C content of 45-47\% (Kandler \& Weiss, 1986). Within the genus Lactobacillus, L. casei is clustered with facultatively heterofermentative ('Group II') species which produce lactic acid from hexose sugars via the Embden-Meyerhof pathway and from pentoses by the 6-phosphogluconate/phosphoketolase pathway (Axelsson, 1998). Growth occurs at $15^{\circ} \mathrm{C}$ but not $45^{\circ} \mathrm{C}$, and requires riboflavin, folic acid, calcium pantothenate, and niacin (Kandler \& Weiss 1986). Previously, four subspecies of $L$. casei were recognized: L. casei subsp. casei, L. casei subsp. pseudoplantarum, L. casei subsp. rhamnosus, and L. casei subsp. tolerans (Kandler \& Weiss 1986). However, recent phylogenetic studies have led to proposals that members of the L. casei group be divided into three species: L. rhamnosus, L. zeae and L. casei, with $L$. casei ATCC 334 as the neotype strain for the latter species (Collins et al. 1989; Dellaglio et al. 1991; Dicks et al. 1996; Mori et al. 1997; Chen et al. 2000).

Members of the L. casei cluster are remarkably adaptive, and may be isolated from raw and fermented dairy products, fresh and fermented plant products, and the reproductive and intestinal tracts of humans and other animals (Kandler \& Weiss 1986). Industrially, L. casei have application as human probiotics (health-promoting live cultures), as acid-producing starter cultures for milk fermentation, and as specialty cultures for the intensification and acceleration of flavor development in certain bacterial-ripened cheese varieties (Kosikowski 1982; Fox et al. 1998; Fonden et al. 2000).

L. casei ATCC 334 was originally isolated as an adventitious contaminant from Emmental cheese. This bacterium, which has an estimated genome size of 
2.2 Mb (Ferrero et al. 1996; Tynkkynen et al. 1999), was selected for genome sequencing because: (a) it was isolated from ripening cheese; (b) it is amenable to transformation and genetic manipulation; and (c) it is the proposed type strain for $L$. casei. Sequence analysis of the $L$. casei ATCC 334 genome is expected to provide a comprehensive view of the enzymes and metabolic pathways that are potential contributors to cheese flavor development. In addition, improved knowledge of global gene regulation and integrative metabolism in $L$. casei will help answer long-standing questions regarding mechanisms for the health-promoting benefits of LAB, identify means by which LAB species grow in harsh environments, highlight the most rational strategies for metabolic and genetic improvements to industrial strains, and improve molecular biology resources for genetic manipulation of dairy lactobacilli.

\section{Acknowledgment}

The Joint Genome Institute of the US Department of Energy is supporting the sequencing effort for this LAB genome. The efforts of B. McManus, T. Hawkins, S. Stilwagen, P. Richardson, and K. Kadner are gratefully acknowledged.

\section{Lactobacillus casei BL23 (contributed by Josef Deutscher and Axel Hartke)}

Lactobacillus casei is a heterofermentative organism widely used in milk fermentation and is therefore of great biotechnological importance. In addition, it belongs to the few bacteria for which probiotic effects have been unequivocally established (for a critical review on probiotics see Marchand \& Vandenplas 2000). 'Healthy' effects of this organism have been observed in numerous studies with men and animals. For example, Lb. casei, which survives transit through the gastrointestinal tract (Yuki et al. 1999), has been shown to positively affect the immune response (Matsuzaki \& Chin 2000; Yasui et al. 1999), to enhance the resistance towards certain forms of diarrhea and to prevent infections by several pathogenic organisms (Wagner et al. 2000; Alvarez et al. 2001). Genetic tools, which allow the transformation of many Lb. casei strains and the construction of predetermined chromosomal mutants carrying deletions or point mutations (Dossonnet et al. 2000; Viana et al. 2000), are available, which together with its probiotic features makes this organism a very interesting subject for further genetic and functional genomic studies.

\section{Genome sequencing status and results}

The genome size of Lb. casei BL23 has previously been estimated to be $2.3 \mathrm{Mb}$, but recent pulsedfield gel electrophoresis analysis (in collaboration with the laboratory of $\mathrm{M}$. Zagorec) revealed a genome size between 2.5 and $2.7 \mathrm{Mb}$. In order to sequence the genome of $L b$. casei BL23 we used a shotgun approach (collaboration between the Laboratoire de Génétique des Microorganismes, INRA-CNRS, Thiverval-Grignon and the Laboratoire Microbiologie de l'Environnement, Université de CAEN). Sequencing $L b$. case $i$ DNA fragments with a mean size of $1.3 \mathrm{~kb}$ from both ends, present in about 8000 isolated clones, allowed us to determine about $90 \%$ of the complete genome. We presently attempt to close the about 560 remaining gaps. Lb. casei BL23 has been cured of plasmid pLZ15 and therefore contains only a single circular chromosome.

Lb. casei seems to be a versatile organism capable of adapting to variable growth conditions. Most intriguingly it seems to be able to utilize a large variety of different carbon sources. This is reflected by the relatively large number of predicted phosphoenolpyruvate:sugar phosphotransferase systems (PTS) (see Table 3). In Lb. casei, the coordinate action of the various carbon utilization systems was found to be controlled by a protein kinase/phosphatase (HprK/P) implicated in carbon catabolite repression and inducer exclusion (Dossonnet et al. 2000). Inactivation of only the phosphatase activity of this bifunctional enzyme had a drastic effect on the growth behavior by preventing the utilization of almost any carbohydrate (Monedero et al. 2001).

\section{Acknowledgments}

We acknowledge the participation of Yanick Auffray, Alain Mazé, Gregory Boël, Ivan Mijakovic, Jean-Christophe Giard, Jean Marie Laplace, Abdellah Benachour, Alain Rincé, Vianney Pichereau and the financial aide from the INRA, the Ministère de la Recherche and the Conseil Régionale de BasseNormandie. 


\section{Lactobacillus brevis ATCC 367 (contributed by Milton Saier)}

Lactobacillus brevis is a heterofermentative bacterium that can be isolated from many different environments. It is frequently used as a starter culture in silage fermentation, sourdough production and LAB-type beer fermentation. In beverages obtained by alcoholic fermentation, lactobacilli may contribute to the quality of the product but may also cause spoilage. Certain L. brevis strains are resistant to hop bittering substances such as isohumulone and are able to grow in beer. Their growth changes the turbidity, flavor and aroma of the beer (Richards \& Macrae 1964). $L$. brevis strains involved in wine fermentation may produce biogenic amines by decarboxylation of precursor amino acids through the action of substrate-specific enzymes (Moreno-Arribas \& Lonvaud-Funel 2001). The ingestion of foods containing high levels of such amines, particularly histamine and tyramine, can lead to several toxicological disturbances (ten Brink et al. 1990; Mariné-Font et al. 1995).

We have studied the involvement of $\operatorname{HPr}($ ser-P) in the regulation of non-PTS permeases in L. brevis (Ye et al. 1994, 1995). When provided with an exogenous energy source such as arginine, galactose grown cells of $L$. brevis transport galactose and the non-metabolizable galactose analogue, thiomethyl- $\beta$ galactoside (TMG), by a sugar: $\mathrm{H}^{+}$symport mechanism (Romano et al. 1987; Djordjevic et al. 2001). $L$. brevis shows very low transformation efficiency by electroporation rendering this bacteria difficult to manipulate. The cryptic plasmid of $14 \mathrm{~kb}$ from L. brevis has recently been sequenced and will be used in the development of novel vectors and essential genetic tools.

\section{Acknowledgment}

The Joint Genome Institute of the US Department of Energy is supporting the sequencing effort for this LAB genome. The efforts of G. Lorca, T. Hawkins, S. Stilwagen, P. Richardson, and K. Kadner are gratefully acknowledged.
Pediococcus pentosaceus ATCC 25745 (contributed by Jeffery Broadbent and James Steele)

Phylogenetically Pediococcus and Lactobacillus form a super-cluster that can be divided in to two subclusters, all species of Pediococcus fall within the Lactobacillus casei-Pediococcus sub-cluster. Morphologically, pediococci and lactobacilli (rods) are distinct. The formation of tetrads via cell division in two perpendicular directions in a single plane is a distinctive characteristic of pediococci. Pediococcus can be described as 'the only acidophilic, homofermentative, LAB that divide alternatively in two perpendicular directions to form tetrads' (Simpson \& Taguchi 1995). Lactic acid is produced from hexose sugars via the Embden-Meyerhof pathway and from pentoses by the 6-phosphogluconate/phosphoketolase pathway (Axelsson, 1998).

Strains of $P$. pentosaceus have been reported to contain between three and five resident plasmids (Graham \& McKay 1985). Plasmid-linked traits include the ability to ferment raffinose, melibiose, and sucrose, as well as, the production of bacteriocins (Daeschel \& Klaenhammer 1985; Gonzalez \& Kunka 1986). Plasmids can be conjugally transferred between $P e$ diococcus and Enterococcus, Streptococcus, or Lactococcus (Gonzalez \& Kunka 1983). Electroporation has been utilized to introduce plasmids into pediococci, including P. pentosaceus (Kim et al. 1992; Caldwell 1996).

P. pentosaceus can be isolated from a variety of plant materials and bacterial-ripened cheeses. This organism is used as an acid-producing starter culture in sausage fermentations, cucumber and green bean fermentations, soya milk fermentations, and silage (Simpson \& Taguchi 1995). P. pentosaceus are also a typical component of the adventitious or non-starter microflora of most cheese varieties during ripening (Beresford et al. 2001). In addition, it has been suggested that this organism may have value as an acidproducing starter culture in the dairy fermentations (Caldwell et al. 1996, 1998).

Genetic studies of $P$. pentosaceus have generated a limited quantity of information on plasmid and chromosomal encoded genes. With only one plasmid and eight unique chromosomal regions sequenced, the vast majority of genes encoding industrially important attributes have yet to be described. Genomic sequence analysis of $P$. pentosaceus genome will help fill key knowledge gaps by providing a comprehensive view 
of the enzymes and metabolic pathways related to: (1) acid and flavor production in fermented meat and vegetable foods; (2) mechanisms by which by $P$. pentosaceus and other non-starter LAB grow and direct flavor development in ripening cheese; and (3) mechanisms by which $P$. pentosaceus and related LAB spoil wine and other alcoholic beverages.

\section{Acknowledgments}

The Joint Genome Institute of the US Department of Energy is supporting the sequencing effort for this LAB genome. The efforts of T. Hawkins, S. Stilwagen, P. Richardson, and K. Kadner are gratefully acknowledged.

\section{Streptococcus thermophilus LMD-9 (contributed by Robert Hutkins)}

Research during the past two decades has revealed that Streptococcus thermophilus has properties that make it one of the most commercially important of all LAB. S. thermophilus is used, along with Lactobacillus spp., as a starter culture for the manufacture of several important fermented dairy foods, including yogurt and Mozzarella cheese. It's use has increased significantly during the past two decades as a result of the tremendous increase in consumption of these products. According to USDA statistics, in 1998, more than 2.24 billion pounds Mozzarella cheese and 1.37 billion pounds of yogurt were produced, respectively, with a combined economic value of nearly $\$ 5$ billion. This increase has led to new demands on the performance and production requirements of such starter cultures. Industrial strains, for example, should be insensitive to bacteriophage, have stable fermentation characteristics, and produce products having consistent flavor and texture properties. Although research on the physiology of S. thermophilus has revealed important information on some of these properties, including sugar and protein metabolism, polysaccharide production, and flavor generation, only recently has the genetic basis for many of these traits been determined.

Currently, several traits in S. thermophilus have been targeted for strain improvement programs (Delcour et al. 2000). Since bacteriophage are responsible for considerable economic losses during cheese manufacture, efforts are underway to engineer restriction and other phage-resistance systems into commercial strains. Enhancing stability and expression of exo- polysaccharides that act as natural thickening agents has also attracted significant attention. Finally, $S$. thermophilus has an important role as a probiotic, alleviating symptoms of lactose intolerance and other gastrointestinal disorders.

The genome of $S$. thermophilus is $1.8 \mathrm{Mb}$, making it among the smallest genomes of all LAB. Although a moderate thermophile, it is phylogenetically related to the more mesophilic lactococci and has a comparable low $\mathrm{G}+\mathrm{C}$ ratio (40\%). Genes coding for metabolic pathways involved in sugar catabolism (Poolman et al. 1989; Vaughan et al. 2001), protein and peptide utilization (Fernandez-Espla et al. 2000; Garault et al. 2002), polysaccharide production (Almirón-Roig et al. 2000), the stress response system (Perrin et al. 1999), and phage resistance mechanisms (Solow \& Somkuti 2000; Burrus 2001) have been sequenced and characterized. Although most strains do not harbor plasmids, other mobile elements have been reported (Guedon et. al. 1995), and techniques for gene transfer and mutagenesis have been developed (Coderre \& Somkuti 1999; Baccigalupi et al. 2000).

\section{Acknowledgments}

The Joint Genome Institute of the US Department of Energy is supporting the sequencing effort for this LAB genome. The efforts of L. Durso, J. Goh, T. Hawkins, S. Stilwagen, P. Richardson, and K. Kadner are gratefully acknowledged.

\section{Streptococcus thermophilus LMG18311 and CNRZ1066 (contributed by Alexander Bolotin, Ross Overbeek and Pascal Hols)}

Streptococcus thermophilus is one of the most economically important LAB used in the manufacture of yogurt and some Swiss- or Italian-type hard cooked cheeses. This Gram-positive, non-sporulating, catalase-negative, facultative-anaerobe coccus produces remarkable quantities of polysaccharides contributing to the rheological properties of fermented products. The comprehensive knowledge of S. thermophilus biology is important for the dairy industry but is rather limited (Delcour et al. 2000). The availability of the whole genome sequence of this species would strongly improve the knowledge of its metabolism and pave the way for engineering of new starter cultures and better control of existing fermentation processes. 
The Life Science Institute at the Catholic University of Louvain (Belgium), the Laboratory of Genetic Microbiology, Jouy en Josas, INRA (France) and Integrated Genomics Inc, Chicago (USA) joined their efforts in determining the genome sequences of two strains of $S$. thermophilus.

\section{Genome sequencing status and results}

The complete sequences were determined by the random shotgun sequencing strategy followed by multiplex PCR described earlier (Bolotin et al. 2001). Sequences of the two strains were determined by construction of two independent sequence datasets containing 20000 random and 1500 primer directed reads for LMG18311 strain and 28000 random and 2000 primer directed reads for CNRZ1066 strain. The assembled genomes were analysed using the ERGO bioinformatics suite. Both genomes contain $\sim 1.8 \mathrm{Mb}$ encoding six rRNA, a compete set of tRNAs, several types of IS, and about 1800 open reading frames. They are organized as a single circular chromosome with 39\% GC content, and show 95\% nucleotide identity. Although the $S$. thermophilus species is characterized as GRAS (Generally Recognized As Safe), several features of its metabolism are similar to that of pathogenic Streptococci. Analysis of the genome has revealed several key aspects of the pathways of carbohydrates, amino acids, nucleotides, polysacharides and lipids metabolism. More than 100 genes involved in the transport of a variety of substrates such as peptides, sugars, metal ions, and cofactors have been identified. The presence of several phage and plasmid related genes indicates the importance of horizontal gene transfer for evolution of S.thermophilus. More information can be found at web sites: http://www.biol.ucl.ac.be/gene/genome/, http://spooky.jouy.inra.fr (restricted access), http:// www.integratedgenomics.com (restricted access)

\section{Acknowledgments}

We thank Benoît Quinquis, Pierre Renault, Alexei Sorokin, and S. Dusko Ehrlich from Génetique Microbienne, INRA; Alla Lapidus, Eugene Goltsman, Mikhail Mazur, Gordon D. Pusch, and Michael Fonstein from Interegated Genomics Inc.; Bénédicte Purnelle, Deborah Prozzi, Katrina Ngui, David Masuy, Frédéric Hancy, Anne Bernard, Sophie Burteau, Marc Boutry, André Goffeau, and Jean Delcour from Unité de Génétique, UCL who participated in the sequencing projects of the two $S$. thermophilus genomes.

\section{Leuconostoc mesenteroides subsp. mesenteroides LA81} (contributed by Fred Breidt)

Leuconostoc species are epiphytic bacteria that are wide spread in the natural environment and play an important role in several industrial and food fermentations. Leuconostoc mesenteroides is a facultative anaerobe requiring complex growth factors and amino acids (Reiter \& Oram 1982; Garvie 1986). Most strains in liquid culture appear as cocci, occuring singly or in pairs and short chains; however, morphology can vary with growth conditions; cells grown in glucose or on solid media may have an elongated or rod-shaped morphology. Cells are Gram-positive, asporogenous and non-motile. A variety of LAB, including Leuconostoc species are commonly found on crop plants (Mundt et al. 1967; Mundt 1970). L. mesenteroides is perhaps the most predominant LAB species found on fruits and vegetables and is responsible for initiating the sauerkraut and other vegetable fermentations (Pederson \& Albury 1969). L. mesenteroides starter cultures also used in some dairy and bread dough fermentations (Server-Busson et al. 1999). Under microaerophilic conditions, a heterolactic fermentation is carried out. Glucose and other hexose sugars are converted to equimolar amount of D-lactate, ethanol and $\mathrm{CO}_{2}$ via a combination of the hexose monophosphate and pentose phosphate pathways (Demoss et al. 1951; Garvie 1986; Gottschalk 1986). Other metabolic pathways include conversion of citrate to diacetyl and acetoin (Cogan et al 1981) and production of dextrans and levan from sucrose (Alsop 1983; Broker 1977). Viscous polysaccharides produced by $L$. mesenteroides are widely recognized as causing product losses and processing problems in the production of sucrose from sugar cane and sugar beets (Tallgren et al. 1999). The first observation of the production of polysaccharide 'slime' from sugar, dates to the earliest days of the science of microbiology; Pasteur (1861) attributed this activity to small cocci, presumably Leuconostoc species. Commercial production dextrans and levans by L. mesenteroides, for use in the biochemical and pharmaceutical industry, has been carried out for more than 50 years (Alsop 1983; Sutherland 1996). Dextrans are used in the manufacture of blood plasma extenders, hep- 
arin substitutes for anticoagulant therapy, cosmetics, and other products (A;sp[ 1983; Kim \& Day 1994; Leathers et al 1995; Sutherland 1996). Another use of dextrans is the manufacture of Sephadex gels or beads, which are widely used for industrial and laboratory protein separations (Sutherland 1996). We have selected L. mesenteroides subsp. mesenteroides LA81 for sequencing. The strain is widely available from a variety of culture collections listed as: ATCC 8293, DSM 20343, NCIB 8023, CCM 1803, NCDO 523, and NRRL B-1118. The strain is generally accepted as a neotype strain for this species; it produces dextran, and was originally isolated from fermenting olives.

\section{Acknowledgments}

The Joint Genome Institute of the US Department of Energy is supporting the sequencing effort for this LAB genome. The efforts of V. Plengvidhya, T. Hawkins, S. Stilwagen, P. Richardson, and K. Kadner are gratefully acknowledged.

\section{Oenococcus oeni PSU-1 (ATCC BAA-331) (contributed by David Mills)}

Oenococcus oeni (formerly called Leuconostoc oenos) is a lactic acid bacterium that occurs naturally in fruit mashes and related habitats (VanVuuren \& Dicks 1993). O. oeni is employed commercially to carry out the malolactic conversion, an important secondary fermentation in the production of wine (Kunkee 1991). $O$. oeni is a facultative anaerobe and one of the most acid- and alcohol-tolerant LAB. O. oeni shares relatively little DNA homology with the other genera in the Leuconostoc branch of the LAB (Dellaglio et al. 1995).

Perhaps the most studied aspect of $O$. oeni is its ability to carry out the malolactic conversion. This involves uptake of malate, decarboxylation to L-lactic acid and $\mathrm{CO}_{2}$, and subsequent export of end products. The malolactic conversion generates energy for the cell in the form of a proton motive force (Salema et al. 1996). Recently the genes encoding the malate decarboxylase ( $m l e A)$ and malate permease (mleP) have been cloned and characterized (Labarre et al. 1996a,b). Other chromosomal genes from $O$. oeni that have been characterized include: histidine decarboxylase (Coton et al. 1998), $\alpha$-acetolactic acid decarboxylase (Garmyn et al. 1996), stress-related genes (Jobin et al. 1997, 1999), genes involved in arginine metabolism
(Tonon et al. 2001) and rDNA genes (Martinez-Murcia $\&$ Collins 1990). Several genetic elements from $O$. oeni have been characterized including bacteriophages (Gindreau et al. 1997; Gindreau \& Lonvaud-Funel 1999), and plasmids (Fremaux et al. 1993). In addition, the conjugative transposon $\mathrm{Tn} 916$ has been mobilized into the $O$. oeni genome (Zuniga et al. 1996b).

Many researchers have examined the diversity of $O$. oeni strains within and around wineries. Studies have employed various molecular typing methods (protein profiling, plasmid profiling, RAPD, PFGE, rDNA RFLP, etc.) to discern regional differences in strains. An outcome of this analysis is the general view that $O$. oeni is a genetically homogenous species (Zapparoli et al. 2000).

The strain sequenced in this project, $O$. oeni PSU1 (ATCC BAA-331), was originally isolated at Penn State University from red wine undergoing a spontaneous malolactic fermentation (Beelman et al. 1977). PSU-1 was shown to reliably induce the malolactic fermentation in wines and is currently employed commercially (Beelman et al. 1980). While the O. oeni is considered homogenous species, the strain PSU-1 was previously shown to be representative of the larger of two divergent groupings (Tenreiro et al. 1994). An extensive physical map of PSU-1 generated by Ze-Ze et al. 1998, 2000) has tremendously aided sequence compilation and genome scaffolding operations.

\section{Acknowledgments}

This project was supported by the US Department of Energy-Joint Genome Institute, the American Vineyard Foundation, and the California Competitive Grants Program for Research in Viticulture and Enology. The efforts of C. M. Joseph, K. Ranstiou, T. Hawkins, S. Stilwagen, P. Richardson, and K. Kadner are gratefully acknowledged.

\section{Oenococcus oeni IOEB 8413 (contributed by Jean Guzzo)}

Oenococcus oeni is a LAB most often responsible for an important step in the winemaking process, the malolactic fermentation (MLF). The main transformation is decarboxylation of malic acid to lactic acid. MLF leads to a natural decrease of acidity, together with an enhancement of stability and quality of wine. Normally, it occurs spontaneously after alcoholic fer- 
mentation, but in some wines the environment is so hostile to bacterial growth that MLF is delayed or even totally prevented. To solve this problem, winemakers use malolactic starters prepared by the industrial culture of selected strains. The laboratory of microbiology, UMR INRA, from Dijon University and the laboratory of biotechnology and applied microbiology, UA INRA, from Bordeaux University, in collaboration with GENOME Express, have determined the complete nucleotide sequence of the chromosome of O.oeni IOEB8413, a strain isolated from Bordeaux wine. The knowledge of the $O$. oeni genome represents a considerable value for developing new tools for the control of malolactic fermentation in wine.

\section{Genome sequencing status and results}

We first sequenced two random small insert and large insert libraries to favour the scaffold formation between sequence contigs during the assembly stage. Subsequently primers were designed for gap closure sequencing by gene walking and multiplex PCR approaches. The sequenced contigs were assembled using the Phred and Phrap software packages. The current assembly represents 1753879 nucleotides and a $\mathrm{G}+\mathrm{C}$ content of $37.9 \%$. At this stage, early annotation has been undertaken in order to improve the finishing step. The annotation was performed using the GenoAnnot $^{t m}$ software (Geno*tm ${ }^{* t a t f o r m), ~ a n ~ i n t e g-~}$ rated computer environment specialised in large-scale sequence annotation. A first pass in an automatic mode with well-dedicated annotation strategies revealed a total of 1784 putative coding sequences, 43 tRNA and 588 predicted rho-independant terminators. Functional annotation was then based on similarity searches with the Blast programs family. Preliminary Blast analysis of the current assembly revealed two ribosomal RNA operons, the presence of three different IS elements in several copies, and protein-coding genes belonging to prophages. Some functional categories of proteins are being studied in detail: stress proteins, transcriptional regulators, central carbon metabolism enzymes and transporters, proteins involved in nitrogen assimilation and the membrane anabolic pathway.

\section{Acknowledgments}

We thank Aline Lonvaud-Funel (University of Bordeaux) and Yves Vandenbrouck (GENOME Express) for their contribution to this work.

\section{Brevibacterium linens BL2 Bio (contributed by Bart Weimer)}

The Brevibacterium genus is a heterogeneous mixture of coryneform organisms that have particular application to industrial production of vitamins, amino acids for fine chemical production, and are commonly used in cheese production (Amador et al. 1999; Rattray $\&$ Fox 1999). This genus contains nine species from diverse habitats, such as soil, poultry, fish, human skin, and food. While Brevibacterium linens is phenotypically similar to Arthrobacter globiformis, cellular pigmentation, cell wall composition, DNA/DNA hybridization and 5s RNA analysis show that Brevibacterium is distinctly different (Park et al. 1987). PFGE analysis indicates that diversity within the species is related to polymorphisms in the $16 \mathrm{~S}$ rRNA genes with genome sizes that range from 3.2 and 3.9 Mbp (Lima $\&$ Correia 2000).

$B$. linens is a non-motile, non-spore forming, nonacid fast, Gram-positive coryneform that tolerates high salt concentrations (8-20\%) and is capable of growing in a broad $\mathrm{pH}$ range (5.5-9.5), with an optimum of $\mathrm{pH}$ 7.0. They also survive carbohydrate starvation and drying for extended periods (Boyaval et al. 1985). B. linens is unusual as they produce base as they grow, raising the $\mathrm{pH}$ to $\sim 9.5$ within $24-36$ h. Recent interest in $B$. linens has focused around their ability to produce a self-processing extracellular protease (Rattray et al. 1997; Weimer et al. 2000), their ability to produce high levels of volatile sulfur compounds (Ferchichi et al. 1985; Dias \& Weimer 1998a,b), bacteriocin production (Valdes-Stauber \& Scherer 1996), cell-membrane-associated carotenoid pigment production (Arrach et al. 2001), and aromatic amino acid metabolism (Leuschner \& Hammes 1998; Ummadi \& Weimer 2001). These organisms are also noted for their metabolize heterocyclic and polycyclic ring structures-a trait that is not associated with other bacteria but is common in fungi. Of particular note is the degradation of insecticides (including DTT and DDE). These organisms also metabolize amino acids, particularly aromatic amino acids, to produce plant growth hormones.

\section{Acknowlegments}

The Joint Genome Institute of the US Department of Energy is supporting the sequencing effort for this LAB genome. The efforts of T. Hawkins, S. Stil- 
wagen, P. Richardson, and K. Kadner are gratefully acknowledged.

\section{Propionibacterium freudenreichii ATCC 6207 (contributed by Herman Pel)}

Propionibacteria are high G+C Gram-positive bacteria belonging to the class of Actinobacteria that prefer anaerobic growth conditions and have a peculiar physiology. They produce propionate as their major fermentation product. Propionate fermentation yields more energy and, consequently, biomass than any other anaerobic microbial fermentation. Furthermore, propionibacteria utilize polyphosphate and pyrophosphate instead of ATP for several energy-dependent reactions and their metabolism is tuned to synthesize high levels of porphyrins, in particular B12.

DSM Food Specialties uses a classical dairy microorganism Propionibacterium freudenreichii to produce vitamin B12 for feed applications. Vitamin B12 is a highly complex but essential vitamin that can only be produced economically through the fermentation of microorganisms. Friesland Coberco Dairy Foods (FCDF) is a world player in cheese production. Propionibacteria have long been employed in the production process of Swiss-type cheeses for which they are indispensable for the typical eye-formation and production of characteristic taste components.

\section{Genome sequencing status and results}

The lack of fundamental physiological knowledge of propionibacteria hampers their efficient industrial exploitation. DSM Food Specialties and Friesland Coberco Dairy Foods have therefore in a combined effort sequenced and annotated the genome of the P. freudenreichii type strain ATCC 6207. A total of 2641522 base pairs were sequenced using a shotgun approach resulting in 12 contigs. The genome sequence revealed a GC content of $67 \%$ and was found to contain at least 2552 open reading frames. The annotated genome, including the resulting blueprint of the metabolic capabilities of the cell, forms a solid basis for the use of powerful tools such as transcriptomics and metabolomics to analyze the metabolic response of $P$. freudenreichii to genetic and environmental changes.

\section{Acknowledgments}

Jan Sikkema (FCDF), Jan Hunik (DSM Food Speciaties) and Albert van Ooyen (DSM Food Specialties) are greatfully acknowledged for their contribution and support to this work. The Propionibacterium freudenreichii genome was sequenced by Qiagen (www.qiagen.com) The genome was annotated by Biomax Informatics (www.biomax.de).

\section{Bifidobacterium breve NCIMB 8807 (contributed by: Douwe van Sinderen)}

Species of the genus Bifidobacterium are Grampositive bacteria, strictly anaerobic, fermentative rods, often Y-shaped or clubbed at the end and contain DNA with a relatively high $\mathrm{G}+\mathrm{C}$ content. They represent a major element in the microflora of the human gastrointestinal tract. They are considered to have a significant role in maintaining the good health of the human host, while there is mounting evidence pointing to the activity of these bacteria in mediating other positive health attributes such as the alleviation of lactose tolerance, stimulation/potentiation of the immune system, and production of vitamins and antimicrobials. Bifidobacteria have been shown to be the predominant species in the gastrointestinal tract of infants, and represent the third most numerous species encountered in the colon of adult humans, considerably outnumbering other groups such as Lactobacillus species. The role of these bacteria in human health has stimulated significant interest in the health care and food industries, and has highlighted the position of these bacteria in the development of functional and pharma foods, which would contain these bacteria as active ingredients.

Despite growing consumer interest, key aspects regarding Bifidobacterium species, such as metabolic activities (particularly relating to catabolism of prebiotics) and physiology are still poorly understood. The determination of the complete genome of the $B$. breve strain NCIM 8807 (National Collection of Industrial and Marine bacteria, Aberdeen, Scotland), an isolate from nursling stools, was undertaken as a first step towards the molecular analysis of a probiotic $B i$ fidobacterium species. This plasmid-free strain was selected because it is reasonably easy to transform ( $\pm 10^{4}$ transformants per $\mu \mathrm{g}$ of plasmid DNA), shows good adherence properties to epithelial cells, and exhibits reproducible growth properties and moderate tolerance to oxidative, osmotic and acid stresses. 


\section{Genome sequencing status and results}

Random sequences were obtained using a small-insert (2-4 kb) plasmid bank and a large insert (20-35 $\mathrm{kb})$ cosmid library generating a total of roughly 10.5 million of raw sequence data (approximately 4.4fold redundancy). These sequences have each been checked for quality and contaminating cloning vector sequences, and subsequently been used for an overall assembly by means of a combination of the Staden software package, and PHRED/PHRAP. This resulted in an initial assembly into 376 contigs, which were then examined individually for internal joints to reduce the total number of contigs to 250 . Gap closure by primer walking is now ongoing and has reduced the number of contigs to 140 , representing a total DNA sequence of $2.43 \mathrm{Mb}$. Preliminary analysis of the obtained sequence has revealed quite a high number of IS elements, and a large number of genes predicted to be involved in the degradation of poly- and oligosaccharides, e.g., arabinogalactan endo-1,4- $\beta$-galactosidase and $\alpha$-mannosidase. Four rRNA-encoding operons have sofar been identified, while the calculated $\mathrm{G}+\mathrm{C}$ content of the genome is roughly $53 \%$.

\section{Acknowledgments}

Funding of this work was obtained through the Higher Education Authority Programme for Research in Third Level Institutions, Cycle 1 (HEA PRTLI1), and BioResearch Ireland. Sinead Leahy, Sinead Ryan, Jose Antonio Moreno Muñoz, Des Higgins and Gerald Fitzgerald are gratefully acknowledged for their contributions to this work.

\section{Bifidobacterium longum DJO10A (contributed by Daniel O'Sullivan)}

Bifidobacteria are anaerobic, Gram-positive, irregular or branched rod-shaped bacteria that are commonly found in the intestines of humans and most animals and insects. They were first isolated and described over 100 years ago from human feces and were quickly associated with a healthy GI tract due to their numerical dominance in breast-fed infants compared to bottle-fed infants (Tissier 1899, 1906). While they were first grouped in the genus Bacillus, the genus Bifidobacterium was proposed in the 1920s (Orla-Jensen 1924). However, there was not a taxonomic consensus for this new genus and for much of the 20th century, they were classified in the genus Lactobacillus, due to their rod-like shapes and obligate fermentative characteristics. However, the accumulation of studies detailing DNA hybridizations, $\mathrm{G}+\mathrm{C}$ content and unique metabolic capabilities resulted in the resurrection of the Bifidobacterium genus. They are characterized by a unique hexose metabolism that occurs via a phosphoketolase pathway often termed the 'bifid shunt'. Fructose-6-phosphate phosphoketolase (F6PPK) is a key enzyme of the 'bifid shunt' and its presence is the most common diagnostic test for this genus, as it is not present in other Gram-positive intestinal bacteria.

The genus is comprised of 31 characterized species, 11 of which have been detected in human feces (Tannock 1999). B. longum is often the dominant species detected in humans and is the only species to regularly harbor plasmids. It is a leading member of the probiotic bacteria due to numerous studies that have provided a growing body of evidence for its role in a myriad of potential health benefits. These include diarrhea prevention in antibiotic treated patients (Black et al. 1991), cholesterol reduction (Dambekodi \& Gilliland 1998), alleviation of lactose intolerance symptoms (Jiang et al. 1996), immune stimulation (Takahashi et al. 1998), and cancer prevention (Reddy \& Rivenson 1993). This myriad of potential health benefits attributed to the B. longum species clearly illustrates that this species possesses many very interesting characteristics. It is anticipated that identification and functional analysis of the genetic determinants involved in these activities will strengthen the evidence for the involvement of $B$. longum in these significant health benefits. Selection of suitable strains for probiotic purposes is very difficult as inherent characteristics of strains of $B$. longum that are necessary for its survival and competition in the human large intestine are currently very poorly understood (O'Sullivan 2001). The use of the sequenced genome in microarray analysis should reveal the pertinent traits that are important for these bacteria to attain dominance in these complex ecosystems.

\section{Acknowledgments}

The Joint Genome Institute of the US Department of Energy is supporting the sequencing effort for this LAB genome. The efforts of JU-H. Lee, J. Halgersen, T. Hawkins, S. Stilwagen, P. Richardson, and K. Kadner are gratefully acknowledged. 


\section{Bifidobacterium longum NCC2705 (contributed by Fabrizio Arigoni)}

Bifidobacteria are obligate anaerobes in the Actinomycetales branch of the high $\mathrm{G}+\mathrm{C}$ Gram-positive bacteria. There are at least 32 species of bifidobacteria, largely isolated from the GITs of many mammals as well as chickens and honeybees (Biavati \& Mattarelli 2001). They are among the first colonizers of the sterile GITs of newborns and predominate until weaning when they are surpassed by other groups (Harmsen et al. 2000; Favier et al. 2002). Although the bifidobacteria represent $<6 \%$ of the adult fecal flora, their presence has been associated with beneficial health effects (Biavati \& Mattarelli 2001). For example, some studies showed that infant formula containing bifidobacteria reduces incidence of diarrhea (Saavedra et al. 1994). These types of studies have led to widespread use of bifidobacteria as components of health-promoting foods (probiotics). Although foods containing bifidobacteria are widely consumed probiotics, there is only fragmentary information about the physiology, ecology, and genetics of any one species. To rapidly increase knowledge and understanding of bifidobacterial biology and their complex interactions with their human hosts and GIT microflora, we determined and extensively analyzed the genome sequence of a $B$. longum strain isolated from infant feces.

\section{Genome sequencing status and results}

The genome sequence of $B$. longum $\mathrm{NCC} 2705$ was determined by shotgun-sequencing of randomly-cloned, 1.5- and 3-kb fragments. ORFs were identified with ORPHEUS (Pedant-Pro; Biomax Informatics). Total genome sequence analysis of $B$. longum revealed a large 2256646-bp chromosomal replicon and a small 3626-bp plasmid replicon that is $89 \%$ identical to pKJ36 (Genbank AF139129). The average G+C content was $60.1 \%$, although six regions had much lower $\mathrm{G}+\mathrm{C}$ content. The chromosome contains four nearly identical $r r n$ operons and 57 tRNAs. We identified 1730 probable coding regions, representing $86 \%$ of the genome. The average gene length was $1100 \mathrm{bp}$, and a specific or general function was assigned to approx. $70 \%$ of them. We were able to attribute $78 \%$ of the predicted proteins to a COG family. The percentages of predicted proteins assigned to COGs in each of the 18 defined functional categories (Tatusov et al. 2001) were similar to those for other prokaryotes, except for an unusual number ( $>8.5 \%$ ) assigned to the carbohydrate transport-metabolism category. This suggests that $B$. longum is well adapted to take advantage of the wide diversity and fluctuations in the nutrient composition in the colon. In addition, we observed that gene duplication and horizontal gene transfer have played an important part in this physiological adaptation. Using SignalP (Nielsen et al. 1997), we identified approximately 200 proteins with probable Sec-type signal peptides. Of these 59 were predicted as surface-associated lipoproteins (PROSITE accession PS00013) and 26 as solute-binding proteins of $\mathrm{ABC}$ transporter systems.

\section{Acknowledgments}

M.A. Schell, M. Karmirantzou, B. Snel, B. Berger, D. Vilanova, G. Pessi, P. Bork, T. Pohl, G. Bothe, M.C Zwahlen, M. Delley are sincerely thanked for their contribution to this work.

\section{References}

Ahrne S, Nobaek S, Jeppsson B, Adlerberth I, Wold AE \& Molin G (1998) The normal Lactobacillus flora of healthy human rectal and oral mucosa. J. Appl. Microbiol. 85: 88-94.

Almirón-Roig E, Mulholland F, Gasson MJ \& Griffin AM (2000) The complete cps gene cluster from Streptococcus thermophilus NCFB 2393 involved in the biosynthesis of a new exopolysaccharide. Microbiology. 146: 2793-2802.

Alsop RM (1983) Industrial production of dextrans. In: Bushell ME (Ed) Progress in Industrial Microbiology (pp 1-42). Elsevier, New York.

Altermann E, Klein JR \& Henrich B (1999) Primary structure and features of the genome of the Lactobacillus gasseri temperate bacteriophage (phi) adh. Gene 236: 333-346.

Alvarez S, Herrero C, Bru E \& Perdigon G (2001) Effect of Lactobacillus casei and yogurt administration on prevention of Pseudomonas aeruginosa infection in young mice. J. Food Prot. 64: 1768-1774.

Amador E, Castro JM, Correia A \& Martin JF (1999) Structure and organization of the rrnD operon of Brevibacterium lactofermentum: analysis of the 16S rRNA gene. Microbiology 145: 915-924.

Arrach N, Fernandez-Martin R, Cerda-Olmedo E \& Avalo J (2001) A single gene for lycopene cyclase, phytoene synthase, and regulation of carotene biosynthesis in Phycomyces. Proc. Natl. Acad. Sci. 98: 1687-1692.

Axelsson L (1998) Lactic acid bacteria: classification and physiology. In: Salminen S \& Von Wright A (Eds) Lactic Acid Bacteria: Microbiology and Functional Aspects, 2nd edition (pp 1-72). Marcel Dekker, New York.

Baccigalupi L, Naclerio G, de Felice M \& Ricca E (2000) Efficient insertional mutagenesis in Streptococcus thermophilus. Gene 258: 9-14.

Barefoot SF \& Klaenhammer TR (1983) Detection and activity of lactacin B, a bacteriocin produced by Lactobacillus acidophilus. Appl. Environ. Microbiol. 45: 1808-1815. 
Beelman RB, Gavin A III \& Keen RM (1977) A new strain of Leuconostoc oenos for induced malo-lactic fermentation in eastern wines. Am. J. Enol. Vitic. 28: 159-165.

Beelman RB, McArdle FJ \& Duke GR (1980) Comparison of Leuconostoc oenos strains ML-34 and PSU-1 to induce malolactic fermentation in Pennsylvania red table wines. Am. J. Enol. Viticult. 31: 269-276.

Beimfohr C, Ludwig W \& Schleifer K-H (1997) Mosaic structure of large regions of the Lactococcus lactis subsp. cremoris chromosome. System. Appl. Microbiol. 20: 216-221.

Beresford TP, Fitzsimons NA, Brennan NL \& Cogan TM (2001) Recent advances in cheese microbiology. Int. Dairy J. 11: 259274.

Bernet M-F, Brassart D, Neeser J-R \& Servin AL (1994) Lactobacillus acidophilus La1 binds to cultured human intestinal cell lines and inhibits cell attachment and cell invasion by enterovirulent bacteria. Gut 35: 483-489.

Bernet-Camard M-F, Liévin V, Brassart D, Neeser J-R, Servin AL \& Hudault S (1997) The human Lactobacillus acidophilus strain La1 secretes a non bacteriocin antibacterial substance active in vitro and in vivo. Appl. Environ. Microbiol. 63: 2747-2753.

Bhowmik T \& Steele JL (1993) Development of an electroporation procedure for gene disruption in Lactobacillus helveticus CNRZ32. J. Gen. Microbiol. 139: 1433-1439.

Bhowmik T, Fernández L \& Steele JL (1993) Gene replacement in Lactobacillus helveticus CNRZ 32. J. Bacteriol. 175: 63416344.

Biavati B \& Mattarelli P (2001) The family Bifidobacteriaceae. In: Dworkin M, Falkow S, Rosenberg E, Schleifer KH \& Stackebrandt E (Eds) The Prokaryotes (pp 1-70). Springer, New York

Black F, Einarsson K, Lidbeck A, Orrhage K \& Nord CE (1991) Effect of lactic acid producing bacteria on the human intestinal microflora during ampicillin treatment. Scand. J. Infect. Dis. 23: 247-254.

Bolotin A, Mauger S, Malarme K, Ehrlich SD \& Sorokin A (1999) Low-redundancy sequencing of the entire Lactococcus lactis IL1403 genome. Antonie van Leeuwenhoek 76: 27-76.

Bolotin A, Wincker P, Mauger S, Jaillon O, Malarme K, Weissenbach J, Ehrlich SD \& Sorokin A (2001) The complete genome sequence of the lactic acid bacterium Lactococcus lactis ssp. lactis IL1403. Genome Res. 11: 731-753.

Bolotin A, Ehrlich SD \& Sorokin A (2002) Studies of genomes of dairy bacteria Lactococcus lactis. Sci. Aliments (in press)

Boyaval P, Boyaval E \& Desmazeaud MJ (1985) Survival of Brevibacterium linens during nutrient starvation and intracellular changes. Arch. Microbiol. 141: 128-132.

ten Brink B, Damink C, Joosten HMLJ \& Huis inpt Veld JHJ (1990) Ocurrence and formation of biologically active amines in foods. Int. J. Food Microbiol. 11: 73-84.

Broadbent JR (2001) Genetics of lactic acid bacteria. In: Steele JL \& Marth EH (Eds) Applied Dairy Microbiology, 2nd ed. Marcel Dekker, New York.

Broker BE (1977) Ultrastructural surface changes associated with dextran synthesis by Leuconostoc mesenteroides. J. Bacteriol. 131: 288-92.

Burrus V, Bontemps C, Decaris B \& Guédon G (2001) Characterization of a novel type II restriction-modification system, Sth368I, encoded by the integrative element ICESt1 of Streptococcus thermophilus CNRZ368. Appl. Environ. Microbiol. 67: $1522-1528$.

Caldwell S, McMahon DJ, Oberg CJ \& Broadbent JR (1996) Development and characterization of lactose-positive Pediococcus species for milk fermentation. Appl. Environ. Microbiol. 62: 936-941.

Caldwell S, Hutkins RW, McMahon DJ, Oberg CJ \& Broadbent JR (1998) Lactose and galactose uptake by genetically engineered Pediococcus species. Appl. Microbiol. Biotechnol. 49: 315-320.

Champomier-Verges M-C, Chaillou S, Cornet M \& Zagorec M (2002) Lactobacillis sakei: recent developments and future prospects. Res. Microbiol. 153: 115-123.

Chen H, Lim CK, Lee YK \& Chan YN (2000) Comparative analysis of the genes encoding 23S-5S rRNA intergenic spacer regions of Lactobacillus casei-related strains. Int. J. Syst. Evol. Microbiol. 50: 471-478.

Chevallier B, Hubert JC \& Kammerer B (1994) Determination of chromosome size and number of rn loci in Lactobacillus plantarum by pulsed-field gel electrophoresis. FEMS Microbiol. Lett. 120: 51-56.

Cho JS, Choi YJ \& Chung DK (2000) Expression of Clostridium thermocellum endoglucanase gene in Lactobacillus gasseri and Lactobacillus johnsonii and characterization of the genetically modified probiotic lactobacilli. Curr. Microbiol 40: 257-63.

Christensen JE, Dudley EG, Pederson JR \& Steele JL (1999) Peptidases and amino acid catabolism in lactic acid bacteria. Antonie van Leeuwenhoek 76: 217-246.

Clark RH, Russell WM \& Klaenhammer TR (2000) Distribution of Lactobacillus acidophilus among a variety of cultured foods and probiotics. Abstracts, Annual IFT Meeting of the Institute of Food Technologists, Dallas, TX, 10 June, 2000

Coderre PE \& Somkuti GA (1999) Cloning and expression of the pediocin operon in Streptococcus thermophilus and other lactic fermentation bacteria. Curr. Microbiol. 39: 295-301.

Cogan TM (1987) Co-metabolism of citrate and glucose by Leuconostoc spp.: effects on growth, substrates and products. J. Appl. Bacteriol. 63: 551-58.

Cogan TM, O'Dowd M \& Mellerick D (1981) Effects of sugar on acetoin production from citrate by Leuconostoc lactis. Appl. Environ. Microbiol. 41: 1-8.

Collins MD, Phyllips BA \& Zanoni P (1989) Deoxyribonucleic acid homology studies of Lactobacillus casei, Lactobacillus paracasei sp. nov., subsp. paracasei and subsp. tolerans, and Lactobacillus rhamnosus sp. nov., comb. nov. Int. J. Syst. Bacteriol. 39: 105-108.

Conway PL, Gorbach SL \& Goldin BR (1987) Survival of lactic acid bacteria in the human stomach and adhesion to intestinal cells. J. Dairy Sci. 70: 1-12.

Coton E, Rollan GC \& Lonvaud-Funel A (1998) Histidine carboxylase of Leuconostoc oenos 9204: Purification, kinetic properties, cloning and nucleotide sequence of the $h d c$ gene. J. Appl. Microbiol. 84: 143-151.

Daeschel MA \& Klaenhammer TR (1985) Association of a 13.6megadalton plasmid in Pediococcus pentosaceus with bacteriocin activity. Appl. Environ. Microbiol. 50: 1528-1541.

Dambekodi PC \& Gilliland SE (1998) Incorporation of cholesterol into the cellular membrane of Bifidobacterium longum. J. Dairy Sci. 81: 1818-1824.

Daniel P (1995) Sizing the Lactobacillus plantarum genome and other lactic bacteria species by transverse alternating field electrophoresis. Curr. Microbiol. 30: 243-246.

Daveran-Mingot ML, Campo N, Ritzenthaler P \& Le Bourgeois P (1998) A natural large chromosomal inversion of Lactococcus lactis is mediated by homologous recombination between two insertion sequences. J. Bacteriol. 180: 4834.

Davidson B, Kordis N, Dobos M \& Hillier A (1996) Genomic organization of lactic acid bacteria. Antonie van Leeuwenhoek 70: 161-183. 
Delcher AL, Harmon D, Kasif S, White O \& Salzberg SL (1999) Improved microbial gene identification with GLIMMER. Nuclaic. Acids Res. 27: 4636-4641.

Delcour J, Ferain T \& Hols P (2000) Advances in the genetics of thermophilic lactic acid bacteria. Curr. Opin. Biotechnol. 11: 497-504.

Dellaglio F, Dicks LMT, du Toit M \& Torriani S (1991) Designation of ATCC334 in place of ATCC393 (NCDO 161) as the neotype strain of Lactobacillus casei subsp. casei and rejection of the name Lactobacillus paracasei. Int. J. Syst. Bacteriol. 41: 340-342.

Dellaglio F, Dicks LMT \& Torriani S (1995) The genus Leuconostoc. In: Wood BJB \& Holzapfel WH (Eds) The Genera of Lactic Acid Bacteria, vol. 2, (pp 235-278). Blackie Academic \& Professional, London

Delorme C, Godon J-J, Ehrlich SD \& Renault P (1994) Mosaic structure of large regions of the Lactococcus lactis subsp. cremoris chromosome. Microbiology. 140: 3053-3060.

Demoss RD, Bard RC \& Gunsalus IC 1951. The mechanism of heterolactic fermentation: a new route of ethanol formation. J. Bacteriol. 62: 499-511.

Dias B \& Weimer B (1998a) Conversion of methionine to thiols by lactococci, lactobacilli, and brevibacteria. Appl. Environ. Microbiol. 64: 3320-3326.

Dias B \& Weimer B (1998b) Purification and characterization of methionine $\beta$-lyase from Brevibacterium linens BL2. Appl. Environ. Microbiol. 64: 3327-3331.

Dicks LMT, du Plessis EM, Dellaglio F \& Lauer E (1996) Reclassification of Lactobacillus casei subsp. casei ATCC 393 and Lactobacillus rhamnosus ATCC15820 as Lactobacillus zeae nom. rev., designation of ATCC 334 as the neotype of $L$. casei subsp. casei, and rejection of the name Lactobacillus paracasei. Int. J. Syst. Bacteriol. 46: 337-340.

Djordjevic GM, Tchieu \& Saier MH (2001) Genes involved in control of galactose uptake in Lactobacillus brevis and reconstitution of the regulatory system in Bacillus subtilis. J. Bacteriol. 183: 3224-3236.

Dossonnet V, Monedero V, Zagorec M, Galinier A, Perez-Martinez G \& Deutscher J (2000) Phosphorylation of HPr by the bifunctional HPr Kinase/P-Ser-HPr phosphatase from Lactobacillus casei controls catabolite repression and inducer exclusion but not inducer expulsion. J. Bacteriol. 182: 2582-2590.

Dudez A-M, Chaillou S, Hissler L, Stentz R, Champomier-Verges M-C, Alpert C-A \& Zagorec M 2002. Physiscal and genetic map of the Lactobacillus sakei 23K chromosome. Microbiology, 148: 421-431.

Dunny G \& McKay LL (1999) Group II introns and expression of conjugative transfer functions in lactic acid bacteria. Antonie van Leeuwenhoek 76: 77-88.

Eddy SR (1998) Profile hidden Markov models. Bioinformatics 14: 755-763

Favier CF, Vaughan EE, De Vos WM, \& Akkermans AD (2002) Molecular monitoring of succession of bacterial communities in human neonates. Appl. Environ. Microbiol. 68: 219-226.

Felley CP, Corthésy-Theulaz I, Blanco Rivero J-L, Sipponen P, Kaufmann M, Bauerfeind P, Wiesel PH, Brassart D, Pfeifer A, Blum AL \& Michetti P (2001) Favourable effect of an acidified milk (LC-1) on Heliocobacter pylori gastritis in man. Eur. J. Gastroenterol. Hepatol. 13: 25-29.

Ferchichi M, Hemme D, Nardi M \& Pamboukdjian N (1985) Production of methanethiol from methionine by Brevibacterium linens CNRZ 918. J. Gen. Microbiol. 131: 715.

Fernandez-Espla MD, Garault P, Monnet V \& Rul E (2000) Streptococcus thermophilus cell wall-anchored proteinase: release, purification, and biochemical and genetic characterization. Appl. Environ. Microbiol. 66: 4772-4778.

Ferrero M, Cesena C, Morelli L, Scolari G \& Vescovo M (1996) Molecular characterization of Lactobacillus casei strains. FEMS Microbiol. Lett. 140: 215-219.

Fonden R, Mogensen G, Tanaka R \& Salminen S (2000) Effect of culture-containing dairy products on intestinal microflora, human nutrition and health - current knowledge and future perspectives. International Dairy Federation Bulletin number 352, IDF, Brussels.

Forde A \& Fitzgerald D (1999) Bacteriophage defense systems in lactic acid bacteria. Antonie van Leeuwenhoek 76: 89-113.

Fox PF, McSweeney PLH \& Lynch CM (1998) Significance of non-starter lactic acid bacteria in cheddar cheese. Aust. J. Dairy Technol. 53: 83-89.

Fremaux C, Aigle M \& Lonvaud FA (1993) Sequence analysis of Leuconostoc oenos DNA: organization of pLo13, a cryptic plasmid. Plasmid 30: 212-23.

Fujisawa T, Benno Y, Yaeshima T \& Mitsuoka T (1992) Taxonomic study of the Lactobacillus acidophilus group, with recognition of Lactobacillus gallinarum sp. nov. and Lactobacillus johnsonii sp. nov. and synonymy of Lactobacillus acidophilus group A3 with the type strain of Lactobacillus amylovorus. Int. J. System. Bacteriol. 42: 487-491.

Garault P, Le Bars D, Besset C \& Monnet V (2002) Three oligopeptide-binding proteins are involved in the oligopeptide transport of Streptococcus thermophilus. J. Biol. Chem. 277: 32-39.

Garmyn D, Monnet C, Martineau B, Guzzo J, Cavin J-F \& Divies $\mathrm{C}$ (1996) Cloning and sequencing of the gene encoding alphaacetolactate decarboxylase from Leuconostoc oenos. FEMS Microbiol. Lett. 145: 445-450.

Garvie EI, Farrow JAE \& Phillips BA (1981) A taxonomic study of some strains of streptococci which grow at $10{ }^{\circ} \mathrm{C}$ but not at $45^{\circ} \mathrm{C}$ including Streptococcus lactis and Streptococcus cremoris. Zbl. Bakteriol. Hyg. I Abt. Orig. C 2: 151-165.

Garvie EI (1986) Genus Leuconostoc. In: Sneath PHA, Mair NS, Sharpe ME \& Holt JG (Eds), Bergey's Manual of Systematic Bacteriology, vol 2, 9th ed. (pp 1071-1075). Williams and Wilkins, Baltimore, MD

Gasson MJ (1983) Plasmid complements of Streptococcus lactis NCDO 712 and other lactic streptococci after protoplast-induced curing. J. Bacteriol. 154: 1-9.

Germond JE, Delley M, D'Amico N \& Vincent SL (2001) Heterologous expression and characterization of the exopolysaccharide from Streptococcus thermophilus Sfi39. Eur. J. Biochem. 268: 5149-5156.

Gill HS, Rutherfurd KJ, Prasad J \& Gopal PK (2000) Enhancement of natural and acquired immunity by Lactobacillus rhamnosus (HN001), Lactobacillus acidophilus (HN017) and Bifidobacterium lactis (HN019). Br. J. Nutr. 83: 167-176.

Gill HS, Rutherfurd KJ \& Cross ML (2001a) Dietary probiotic supplementation enhances natural killer cell activity in the elderly: an investigation of age-related immunological changes. J. Clin. Immunol. 21: 264-271

Gill HS, Shu Q, Lin H, Rutherfurd KJ \& Cross ML (2001b) Protection against translocating Salmonella typhimurium infection in mice by feeding the immuno-enhancing probiotic Lactobacillus rhamnosus strain HN001. Med. Microbiol. Immunol. (Berlin) 190: 97-104.

Gindreau E \& Lonvaud-Funel A (1999) Molecular analysis of the region encoding the lytic system from Oenococcus oeni temperate bacteriophage variant phi10MC. FEMS Microbiol. Lett. 171: 231-238. 
Gindreau E, Torlois S \& Lonvaud-Funel A (1997) Identification and sequence analysis of the region encoding the site-specific integration system from Leuconostoc oenos (Oenococcus oeni) temperate bacteriophage phi-10MC. FEMS Microbiol. Lett. 147: 279-285.

Godon J, Delorme C, Ehrlich SD \& Renault P (1992) Divergence of genomic sequences between Lactococcus lactis subsp. lactis and Lactococcus lactis subsp.cremoris. Appl. Environ. Microbiol. 58: 4045-4047.

Gold RS, Meagher Mm, Tong S, Hutkins RW, \& Conway T (1996) Cloning and expression of the Zymomonas mobilis 'Production of ethanol' genes in Lactobacillus casei. Curr. Microbiol. 33: 256-260.

Goldin BR \& Gorbach SL (1980) Effect of milk and Lactobacillus feeding on human intestinal bacterial enzyme activity. Am. J. Clin. Nutr. 39: 756-761.

Goldin BR, Swenson L, Dwyer J, Sexton M \& Gorbach S (1980) Effect of diet and Lactobacillus acidophilus supplements on human fecal bacterial enzymes. J. Natl. Cancer Inst. 64: 255-261.

Gonzalez CF \& Kunka BS (1983) Plasmid transfer in Pediococcus spp.: Intergeneric and intrageneric transfer of pIP501. Appl. Environ. Microbiol. 46: 81-89.

Gonzalez CF \& Kunka BS (1986) Evidence for plasmid linkage of raffinose utilization and associated $\alpha$-galactosidase and sucrose hydrolase activity in Pediococcus pentosaceus. Appl. Environ. Microbiol. 51: 105-109.

Gopal PK, Prasad J, Smart J \& Gill HS (2001) In vitro adherence properties of Lactobacillus rhamnosus DR20 and Bifidobacterium lactis DR10 strains and their antagonistic activity against an enterotoxigenic Escherichia coli. Int. J. Food Microbiol. 67: 207-216.

Gottschalk G (1986) Bacterial Metabolism, 2nd ed. Springer, New York.

Graham DC \& McKay LL (1985) Plasmid DNA in strains of Pediococcus cerevisiae and Pediococcus pentosaceus. Appl. Environ. Microbiol. 50: 532-534.

Granato D, Perotti F, Masserey I, Rouvet M, Golliard M, Servin AL \& Brassart D(1999) Cell surface-associated lipoteichoic acid acts as an adhesion factor for attachment of Lactobacillus johnsonii La1 to human enterocyte-like Caco-2 cells. Appl. Environ. Microbiol. 65: 1071-1077.

Greene JD \& Klaenhammer TR (1994) Factors involved in adherence of lactobacilli to human Caco-2 cells. Appl. Microbiol. 60: 4487-4494.

Guedon G, Bourgoin F, Pebay M, Roussel Y, Colmin C, Simonet JM \& Decaris B (1995) Characterization and distribution of two insertion sequences, IS 1191 and iso-IS 981, in Streptococcus thermophilus: does intergeneric transfer of insertion sequences occur in lactic acid bacteria co-cultures? Mol. Microbiol. 16: 6978.

Haller D, Blum S, Bode C, Hammes WP \& and Schiffrin EJ (2000a) Activation of human PBMC by non-pathogenic bacteria in vitro: evidence of NK cells as primary targets. Infect. Immun. 68: 752759.

Haller D, Bode C, Hammes WP, Pfeifer AMA, Schiffrin EJ \& Blum $S$ (2000b) Non-pathogenic bacteria elicit a differential cytokine response by intestinal epithelial cell/leucocyte co-cultures. Gut 47: 79-87.

Hammes WP \& Vogel RF (1995) The genus Lactobacillus. In: Wood BJB \& Holzapfel WH (Eds) The Genera of Lactic Acid Bacteria (pp 19-54). Chapman \& Hall, London.

Harmsen HJ, Wildeboer-Veloo AC, Raangs GC, Wagendorp AA, Klijn N, Bindels JG \& Welling GW (2000) Analysis of intestinal flora development in breast-fed and formula-fed infants by using molecular identification and detection methods. J. Pediatr. Gastroenterol. Nutr. 30: 61-67.

Hassan AN \& Frank JF (2001) Starter cultures and their use. In: Marth EH \& Steele JL (Eds) Applied Dairy Microbiology, 2nd edition (pp 151-206). Marcel Dekker, Inc, New York.

Heilig HGH, Zoetendal EG, Vaughan EE, Marteau P, Akkermans ADL \& deVos WM (2002) Molecular diversity of Lactobacillus spp. and other lactic acid bacteria in the human intestine as determined by specific amplification of $16 \mathrm{~S}$ ribosomal DNA. Appl. Environ. Microbiol. 68: 14-123.

Hols P, Slos P, Dutot P, Reymund J, Chabot P, Delplace B, Delcour J \& Mercenier A (1997) Efficient secretion of the model antigen M6-gp41E in Lactobacillus plantarum NCIMB 8826. Microbiology 143: 2733-41.

Hughes D (2000) Evaluating genome dynamics: The constraints on rearrangements within bacterial genomes. Genome Biol. 1: Reviews 0006.1-0006.8.

Hofvendahl K \& Hahn-Hagerdal B (2000) Factors affecting the fermentative lactic acid production from renewable resources. Enzyme Microb. Technol. 26: 87-107.

Itoh T, Fujimoto Y, Kawai Y, Toba T \& Saito T (1995) Inhibition of food-borne pathogenic bacteria by bacteriocins from Lactobacillus gasseri. Lett. Appl. Microbiol. 21: 137-141.

Jiang TA, Mustapha A \& Savaiano DA (1996) Improvement of lactose digestion in humans by ingestion of unfermented milk containing Bifidobacterium longum. J. Dairy Sci. 79: 750-757.

Jobin M-P, Delmas F, Garmyn D, Divies C \& Guzzo J. (1997) Molecular characterization of the gene encoding an 18-kilodalton small heat shock protein associated with the membrane of Leuconostoc oenos. Appl. Environ. Microbiol. 63: 609-614.

Jobin M-P, Garmyn D, Divies C \& Guzzo J (1999) The Oenococcus oeni clpX homologue is a heat shock gene preferentially expressed in exponential growth phase. J. Bacteriol. 181: 6634-6641.

Johnson JL, Phelps CF, Cummins CS, London J \& Gasser F (1980) Taxonomy of the Lactobacillus acidophilus group. Int. J. System. Bacteriol. 30: 53-68.

Kandler O (1983) Carbohydrate metabolism in lactic acid bacteria. Antonie van Leeuwenhoek 49: 209-224.

Kandler O \& Weiss N (1986) Genus Lactobacillus. In: Sneath PHA, Mair NS, Sharpe ME \& Holt JG (Eds.) Bergey's Manual of Systematic Bacteriology, vol 2, 9th ed. (pp 1063-1065). Williams and Wilkins, Baltimore, MD.

Kaplan H \& Hutkins RW (2000) Fermentation of fructooligosaccharides by lactic acid bacteria and bifidobacteria. Appl. Environ. Microbiol. 66: 2682-2684.

Kim D \& Day DF (1994) A new process for the production of clinical dextran by mixed-culture fermentation of Lipomyces starkeyi and Leuconostoc mesenteroides. Enzyme Microb. Technol. 16: $844-48$.

Kim WJ, Ray B \& Johnson MC (1992) Plasmid transfers by conjugation and electroporation in Pediococcus acidilactici. J. Appl. Bacteriol. 72: 201-207.

Kirjavainen PV, El-Nezami HS, Salminen SJ, Ahokas JT \& Wright PF (1999) The effect of orally administered viable probiotic and dairy lactobacilli on mouse lymphocyte proliferation. FEMS Immunol. Med. Microbiol. 26: 131-135.

Kitazawa H, Tomioka Y, Matsumura K, Aso H, Mizugaki M, Itoh $\mathrm{T} \&$ Yamaguchi T (1994) Expression of mRNA encoding IFN alpha in macrophages stimulated with Lactobacillus gasseri. FEMS Microbiol. Lett. 120: 315-321.

Klaenhammer TR \& Russell WM (2000) Species of the Lactobacillus acidophilus complex. In: Robinson RK, Batt C \& Patel 
PD (Eds) Encyclopedia of Food Microbiology, Vol. 2, (pp 1151-1157). Academic Press, San Diego, CA.

Kosikowski FV (1982) Cheese and Fermented Milk Foods, 2nd edn. Kosikowski and Assoc., Brooktondale, NY.

Kullen MJ, Sanozky-Dawes RB, Crowell DC \& Klaenhammer TR (2000) Use of DNA sequence of variable regions of the $16 \mathrm{Sr}-$ RNA gene for rapid and accurate identification of bacteria in the Lactobacillus acidophilus complex. J. Appl. Microbiol. 89: 511-518.

Kunkee RE (1991) Some roles of malic acid in the malolactic fermentation in wine making. FEMS Microbiol. Rev. 88: 55-72.

Labarre C, Diviès C \& Guzzo J (1996a) Genetic organization of the mle locus and identification of a mleR-like gene from Leuconostoc oenos. Appl. Environ. Microbiol. 62: 4493-4498.

Labarre C, Guzzo J, Cavin JF \& Diviès C (1996b) Cloning and characterization of the genes encoding the malolactic enzyme and the malate permease of Leuconostoc oenos. Appl. Environ. Microbiol. 62: 1274-1282.

Lawrence RC, Thomas TD \& Terzaghi BE (1976) Reviews of the progress of dairy science: cheese starters. J. Dairy Res. 43: 141193.

Leathers TD, Hayman GT \& Cote GL 1995. Rapid screening of Leuconostoc mesenteroides mutants for elevated proportions of alternan to dextran. Curr. Microbiol. 31: 19-22.

Le Bourgeois P, Lautier M, van den Berghe L, Gasson MJ \& Ritzenthaler P (1995) Physical and genetic map of the Lactococcus lactis subsp. cremoris MG1363 chromosome: comparison with that of Lactococcus lactis subsp. lactis IL1403 reveals a large genome inversion. J. Bacteriol. 177: 2840-2850.

Le Bourgeois P, Daveran-Mingot ML \& Ritzenthaler P (2000) Genome plasticity among related Lactococcus strains: identification of genetic events associated with macrorestriction polymorphisms. J. Bacteriol. 182: 2481-2491.

Leong-Morgenthaler P, Ruettener C, Mollet B \& Hottinger H (1990) Construction of a physical map of Lactobacillus bulgaricus. Proc. Third Symp. Lactic Acid Bact. A28.

Leuschner RG \& Hammes WP (1998) Degradation of histamine and tyramine by Brevibacterium linens during surface ripening of Munster cheese. J. Food Prot. 61: 874-878.

Lima PT \& Correia AM (2000) Genetic fingerprinting of Brevibacterium linens by pulsed-field gel electrophoresis and ribotyping. Curr. Microbiol. 41: 50-55.

Link-Amster H, Rochat F, Saudan KY, Mignot O \& Aeschlimann J-M (1994) Modulation of a specific humoral immune response and changes in intestinal flora mediated through fermented milk intake. FEMS Immunol. Med. Microbiol. 10: 55-64.

Luchansky JB, Muriana PM \& Klaenhammer TR (1988) Application of electroporation for transfer of plasmid DNA to Lactobacillus, Lactococcus, Leuconostoc, Listeria, Pediococcus, Bacillus, Staphylococcus, Enterococcus, and Propionibacterium. Mol. Microbiol. 2: 637-647.

Maguin E, Prevost H, Ehrlich SD \& Gruss A (1996) Efficient insertional mutagenesis in lactococci and other gram-positive bacteria. J. Bacteriol. 178: 931-5.

Marchand J \& Vandenplas Y (2000) Microorganisms administered in the benefit of the host: myths and facts. Eur. J. Gastroenterol. Hepatol. 12: 1077-1088.

Mariné-Font A, Vidal-Carou MC, Izquierdo-Pulido M, VencianaNogués MT \& Hernández-Jover T (1995) Les amines biogénes dans les aliments: leur signification, leur analyse. Ann. Fals. Exp. Chim. 88: 11-140.

Marteau P \& Rambaud JC (1993) Potential of using lactic acid bacteria for therapy and immunomodulation in man. FEMS Microbiol. Rev. 12: 207-222.
Martinez-Murcia AJ \& Collins MD (1990) A phylogenetic analysis of the genus Leuconostoc based on reverse transcriptase sequencing of $16 \mathrm{~S}$ ribosomal RNA. FEMS Microbiol. Lett. 70: $73-84$.

Matsuzaki T \& Chin J (2000) Modulating immune responses with probiotic bacteria. Immunol. Cell. Biol. 78: 67-73.

McKay LL (1985) Roles of plasmids in starter cultures. In: Gilliland SE (Ed) Bacterial Starter Cultures for Food (pp 159-174). CRC Press, Boca Raton, FL.

Milk Industry Foundation (1998) Milk Facts. USA

Mitsuoka T (1992) The human gastrointestinal tract. In: Wood BJB (Ed) The Lactic Acid Bacteria, Vol. 1: The Lactic Acid Bacteria in Health and Disease (pp 69-114). Elsevier Science Publishers, Essex.

Monedero V, Poncet S, Mijakovic I, Fieulaine S, Dossonnet V, Martin-Verstraete I, Nessler S \& Deutscher J (2001) Mutations lowering the phosphatase activity of HPr kinase/phosphatase switch off carbon metabolism. EMBO J. 20: 3928-3937.

Moreno-Arribas V \& Lonvaud-Funel A (2001) Purification and characterization of tyrosine decarboxylase of Lactobacillus brevis IOEB 9809 isolated from wine. FEMS Microbiol. Lett. 195: 103-107.

Mori K, Yamazaki K, Ishiyama T, Katsumata M, Kobayashi K, Kawai Y, Inoue N \& Shinano H (1997) Comparative sequence analyses of the genes coding for 16S rRNA of Lactobacillus casei-related taxa. Int. J. Syst. Bacteriol. 47: 54-57.

Mundt JO (1970) Lactic acid bacteria associated with raw plant food material. J. Milk Food Technol. 33: 550-553.

Mundt JO, Graham WF \& McCarty IE (1967) Spherical lactic acid producing bacteria of southern-grown raw and processed vegetables. Appl. Microbiol. 15: 1303-1308.

National Cheese Institute (1998) Cheese Facts. USA.

Neeser J-R, Granato D, Rouvet M, Servin AL, Teneberg S \& Karlsson K-A. (2000) Lactobacillus johnsonii La1 shares carbohydrate-binding specificities with several enteropathogenic bacteria. Glycobiology. 10: 1193-1199.

Nicolas P, Bize L, Muri F, Hoebeke M, Rodolphe F, Ehrlich SD, Prum B \& Bessières P (2002) Mining Bacillus subtilis chromosome heterogeneities using hidden Markov models. Nucleic Acids Res. 30: 1418-1426.

Nielsen H, Engelbrecht J, Brunak S \& von Heijne G (1997) Identification of prokaryotic and eukaryotic signal peptides and prediction of their cleavage sites. Protein Eng. 10: 1-6.

Orla-Jensen S (1924) La classificationdes des bactéries lactiques. Lait 4: 468-474.

O'Sullivan DJ (2001) Screening of intestinal microflora for effective probiotic bacteria. J. Agric. Food Chem. 49: 1751-1760.

Park YH, Hori H, Suzuki K, Osawa S \& Komagata K (1987) Phylogenetic analysis of the coryneform bacteria by 5S rRNA sequences. J. Bacteriol. 169: 1801-1806.

Pasteur L (1861) Sur la fermentation visquese et la fermentation butyrique. Bull. Soc. Chim. Paris 11: 30-31.

Pederson CS \& Albury MN (1969) The sauerkraut fermentation. NY State Agric. Expt. Sta. (Geneva, NY) Tech. Bull. Bulletin 824.

Pedrosa MC, Golner BB, Goldin BR, Barakat S, Dallal GE \& Russell RM (1995) Survival of yogurt-containing organisms and Lactobacillus gasseriA (ADH) and their effect on bacterial enzyme activity in the gastrointestinal tract of healthy and hypocholorhydric elderly subjects. Am. J. Clin. Nutr. 61: 353-359.

Pérez PF, Minnaard J, Rouvet M, Knabenhans C, Brassart D, De Antoni GL \& Schiffrin EJ (2001) Inhibition of Giardia intestinalis by extracellular factors from Lactobacilli: an in vitro study. Appl. Environ. Microbiol. 67: 5037-5042. 
Perrin C, Guimont C, Bracquart P \& Gaillard JL (1999) Expression of a new cold shock protein of $21.5 \mathrm{kDa}$ and of the major cold shock protein by Streptococcus thermophilus after cold shock. Curr. Microbiol. 39: 342-347.

Poolman B, Royer TJ, Mainzer SE \& Schmidt BF (1989) Lactose transport system of Streptococcus thermophilus: a hybrid protein with homology to the melibiose carrier and enzyme III of phosphoenolpyruvate-dependent phosphotransferase systems. J. Bacteriol. 171: 244-253.

Pouwels PH, Leer RJ, Shaw M, Heijne den Bak-Glashouwer MJ, Tielen FD, Smit E, Martinez B, Jore J \& Conway PL (1998) Lactic acid bacteria as antigen delivery vehicles for oral immunization purposes. Int. J. Food Microbiol. 41: 155-67.

Prasad J, Gill HS, Smart JB \& Gopal PK (1998) Selection and characterisation of Lactobacillus and Bifidobacterium strains for use as probiotics. Int. Dairy J. 8: 993-1002.

Rantsiou K, Phister T, McKay LL, Dunny G \& Mills D (1999) Broad host range mobilization of plasmid derivatives by the lactococcal conjugal element pRS01. Proc. Sixth Symp. Lactic Acid Bact. E13.

Rattray FP \& Fox PF (1999) Aspects of enzymology and biochemical properties of Brevibacterium linens relevant to cheese ripening: a review. J. Dairy Sci. 82: 891-909.

Rattray FP, Fox PF \& Healy A (1997) Specificity of an extracellular proteinase from Brevibacterium linens ATCC 9174 on bovine beta-casein. Appl. Environ. Microbiol. 63: 2468-2471.

Reiter B \& Oram JD (1982) Nutritional studies on cheese starter. 1. Vitamin and amino acid requirements of single strain starters. J. Dairy Res. 29: 63-68.

Richards M \& Macrae RM (1964) The significance of the use of hops in regard to the biological stability of beer . II. The development of resistance to hop resins by strains of lactobacilli. J. Inst. Brewing 70: 484-488.

de Roos NM \& Katan MB (2000) Effects of probiotic bacteria on diarrhea, lipid metabolism, and carcinogenesis: a review of papers published between 1988 and 1998. Am. J. Clin. Nutr. 71: 405-411.

Rozen S \& Skaletsky HJ (1998) Primer3 http://wwwgenome.wi.mit.edu/genome_softwar e/other/primer3.html

Russell WM \& Klaenhammer TR (2001a) Identification and cloning of gus A, encoding a new $\beta$-glucuronidase from Lactobacillus gasseri ADH. Appl. Environ. Microbiol. 67: 1253-1267.

Russell WM \& Klaenhammer TR (2001b) An efficient system for directed integration into the Lactobacillus acidophilus and Lactobacillus gasseri chromosome via homologous recombination. Appl. Environ. Microbiol. 67: 4361-4364.

Saavedra JM, Bauman NA, Oung I, Perman JA \& Yolken RH (1994) Feeding of Bifidobacterium bifidum and Streptococcus thermophilus to infants in hospital for prevention of diarrhoea and shedding of rotavirus. Lancet 344: 1046-1049.

Salama M, Sandine WE \& Giovannoni S (1991) Development and application of oligonucleotide probes for identification of Lactococcus lactis subsp. cremoris. Appl. Environ. Microbiol. 57: 1313-1318.

Salema M, Capucho I, Poolman B, San Romão MV \& Dias MC (1996) In vitro reassembly of the malolactic fermentation pathway of Leuconostoc oenos (Oenococcus oeni). J. Bacteriol. 178: 5537-5539.

Sanders ME \& Klaenhammer TR (2001) Invited review: the scientific basis of Lactobacillus acidophilus NCFM functionality as a probiotic. J. Dairy Sci. 84: 319-331.

Sandine WE (1988) New nomenclature of the non-rod-shaped lactic acid bacteria. Biochemie 70: 519-522.
Schiffrin EJ, Rochat F, Link-Amster H, Aeschlimann J-M \& Donnet-Hughes A (1995) Immunomodulation of human blood cells following the ingestion of lactic acid bacteria. J. Dairy Sci. 78: 491-497.

Schleifer K-H (1987) Recent changes in the taxonomy of lactic acid bacteria. FEMS Microbiol. Rev. 46: 201-203.

Schleifer KH \& Ludwig W (1995) Phylogenetic relationships of lactic acid bacteria. In: Wood BJB \& Holzapfel WH (Eds) The Genera of Lactic Acid Bacteria (pp 7-18). Chapman \& Hall, London.

Serror P, Sasaki T, Ehrlich SD \& Maguin E (2002) Electrotransformation of Lactobacillus delbrueckii subsp. bulgaricus and $L$. delbrueckii subsp . lactis with various plasmids. Appl. Environ. Microbiol. 68: 46-52.

Server-Busson C, Foucaud C \& Leveau J-Y (1999) Selection of dairy Leuconostoc isolates for improtant technological properties. J. Dairy Res. 66: 245-56.

Sheih YH, Chiang BL, Wang LH, Liao CK \& Gill HS (2001) Systemic immunity-enhancing effects in healthy subjects following dietary consumption of the lactic acid bacterium Lactobacillus rhamnosus HN001. J. Am. Coll. Nutr. 20(2 Suppl): 149-56.

Simpson WJ \& Taguchi H (1995) The genus Pediococcus, with notes on the genera Tetratogenococcus and Aerococcus. In: Wood BJB \& Holzapfel WH (Eds) The Genera of Lactic Acid Bacteria (pp 125-172). Chapman \& Hall, London.

Slos P, Dutot P, Reymund J, Kleinpeter P, Prozzi D, Kieny MP, Delcour J, Mercenier A \& Hols P (1998) Production of cholera toxin B subunit in Lactobacillus. FEMS Microbiol. Lett. 169: 29-36.

Solow BT \& Somkuti GA (2000) Molecular properties of Streptococcus thermophilus plasmid pER35 encoding a restriction modification system. Curr. Microbiol. 42: 122-128.

Stuart M, Chou L-S \& Weimer BC (1998) Influence of carbohydrate starvation and arginine on culturability and amino acid utilization of Lactococcus lactis subsp. lactis. Appl. Environ. Microbiol. 65: 665-673.

Steidler L, Robinson K, Chamberlain L, Schofield KM, Remaut E, Le Page RW \& Wells JM (1998) Mucosal delivery of murine interleukin-2 (IL-2) and IL-6 by recombinant strains of Lactococcus lactis coexpressing antigen and cytokine. Infect. Immun. 66: 3183-3189.

Sutherland IW (1996) Extracellular polysaccharides. In: Rehm H-J, Reed G, Puhler A \& Stadler P (Eds) Biotechnology, 2nd ed., Vol 6: Products of Primary Metabolism (pp 613-657). VCH, New York.

Tallgren AH, Airaksinen U, von Weissenberg R, Ojamo H, Kuusisto J \& Leisola M (1999) Exopolysaccharide-producing bacteria from sugar beets. Appl. Environm. Microbiol. 65: 862-64.

Takahashi T, Nakagawa E, Nara T, Yajima T \& Kuwata T (1998) Effects of orally ingested Bifidobacterium longum on the mucosal IgA response of mice to dietary antigens. Biosci. Biotechnol. Biochem. 62: 10-15.

Tannock GW (2000) Identification of lactobacilli and bifidobacteria. Curr. Issues Intest. Microbiol. 1: 39-50.

Tannock GW, Munro K, Harmsen HJ, Welling GW, Smart J \& Gopal PK (2000) Analysis of the fecal microflora of human subjects consuming a probiotic product containing Lactobacillus rhamnosus DR20. Appl. Environ. Microbiol. 66: 2578-2588.

Tatusov RL, DNatale DA, Garkavtsev IV, Tatusova TA, Shankavaram UT, Rao BS, Kiryutin B, Galperin MY, Fedorova ND \& Koonin EV (2001) The COG database: new developments in phylogenetic classification of proteins from complete genomes. Nucleic Acids Res. 29: 22-28.

Tejada-Simon MV \& Pestka JJ (1999) Proinflammatory cytokine and nitric oxide induction in murine macrophages by cell wall 
and cytoplasmic extracts of lactic acid bacteria. J. Food Prot. 62: 1435-44.

Tenreiro R, Santos MA, Paveia H \& Vieira G (1994) Inter-strain relationships among wine leuconostocs and their divergence from other Leuconostoc species, as revealed by low frequency restriction fragment analysis of genomic DNA. J. Appl. Bacteriol. 77: 271-280.

Thompson JK, McConville KJ, McReynolds C \& Collins MA (1999) Potential of conjugal transfer as a strategy for the introduction of recombinant genetic material into strains of Lactobacillus helveticus. Appl. Environ. Microbiol. 65: 1910-1914.

Tissier H (1900) Recherches sur la flore intestinale des nourrissons (etat normal et pathologique) Paris Thèses: 1-253.

Tissier H (1906) Traitement des infections intestinales par la méthode de la flore bactérienne de l'intestin. Crit. Rev. Soc. Biol. 60: 359-361.

Tonon T, Bourdineaud J-P \& Lonvaud-Funel A (2001) The arcABC gene cluster encoding the arginine deiminase pathway of Oenococcus oeni, and arginine induction of a CRP-like gene. Res. Microbiol. 152: 653-661.

Tynkkynen S, Satokari R, Saarela M, Mattila-Sandholm T \& Saxelin M (1999) Comparison of ribotyping, randomly amplified polymorphic DNA analysis, and pulsed-field gel electrophoresis in typing of Lactobacillus rhamnosus and L. casei strains. Appl. Environ. Microbiol. 65: 3908-3914.

Ummadi M \& Weimer BC (2001) Tryptophan metabolism in Brevibacterium linens BL2. J. Dairy Sci. 84: 1773-1782.

Valdes-Stauber N \& Scherer S (1996) Nucleotide sequence and taxonomical distribution of the bacteriocin gene lin cloned from Brevibacterium linens M18. Appl. Environ. Microbiol. 62: $1283-1286$.

Vaughan EE, van den Bogaard PTC, Catzeddu P, Kuipers OP \& de Vos WM (2001) Activation of silent gal genes in the lacgal regulon of Streptococcus thermophilus. J. Bacteriol. 183: 1184-1194.

Vesa T, Pochart P and Marteau P (2000) Pharmacokinetics of Lactobacillus plantarum NCIMB 8826, Lactobacillus fermentum KLD, and Lactococcus lactis Mg 1363 in the human gastrointestinal tract. Aliment. Pharmacol. Ther. 14: 823-828.

Viana R, Monedero V, Dossonnet V, Vadeboncoeur C, PerezMartinez G \& Deutscher J (2000) Enzyme I and HPr from Lactobacillus case $i$ : their role in sugar transport, carbon catabolite repression and inducer exclusion. Mol. Microbiol. 36: 570-584.

van Vuuren HJJ \& Dicks LMT (1993) Leuconostoc oenos: A review. Am. J. Enol. Viticult. 44: 99-112.

Wagner RD, Pierson C, Warner T, Dohnalek M, Hilty M \& Balish E (2000) Probiotic effects of feeding heat-killed Lactobacillus acidophilus and Lactobacillus casei to Candida albicanscolonized immunodeficient mice. J. Food Prot. 63: 638-644.

Walker DC, Aoyama K \& Klaenhammer TR (1996) Electro- transformation of Lactobacillus acidophilus group A1. FEMS Microbiol. Lett. 138: 233-237.

Weimer BC, Yi X \& Brown R (2000) Autocatalytic processing of the protease from Brevibacterium linens BL2: a kinetic analysis for the degradation of casein. International Dairy Federation Biennial Cheese Flavor Conference, Banff, Alberta.

Wells JM, Robinson K, Chamberlain LM, Schofield km \& Le Page RW (1996) Lactic acid bacteria as vaccine delivery vehicles. Antonie van Leeuwenhoek 70: 317-330.

Yasui H, Shida K, Matsuzaki T \& Yokokura T (1999) Immunomodulatory function of lactic acid bacteria. Antonie van Leeuwenhoek 76: 383-389.

Ye JJ \& Saier MH (1995) Cooperative binding of lactose and $\mathrm{HPr}(\mathrm{Ser}-\mathrm{P})$ to the lactose: $\mathrm{H}^{+}$permease of Lactobacillus brevis. Proc. Natl. Acad. Sci. U.S.A. 92: 417-421.

Ye JJ, Reizer J, Cui X \& Saier MH (1994) ATP-dependent phosphorylation of serine in $\mathrm{HPr}$ regulates lactose: $\mathrm{H}^{+}$symport in Lactobacillus brevis. Proc. Natl. Acad. Sci. U.S.A. 91: 31023106.

Yuki N, Watanabe K, Mike A, Tagami Y, Tanaka R, Ohwaki M \& Morotomi M (1999) Survival of a probiotic, Lactobacillus casei strain Shirota, in the gastrointestinal tract: selective isolation from faeces and identification using monoclonal antibodies. Int. J. Food Microbiol. 48: 51-57.

Zapparoli G, Reguant C, Bordons A, Torriani S \& Dellaglio F (2000) Genomic DNA fingerprinting of Oenococcus oeni strains by pulsed-field gel electrophoresis and randomly amplified polymorphic DNA-PCR. Curr. Microbiol. 40: 351-355.

Ze-Ze L, Tenreiro R, Brito L, Santos MA \& Paveia H (1998) Physical map of the genome of Oenococcus oeni PSU-1 and localization of genetic markers. Microbiology 144: 1145-1156.

Ze-Ze L, Tenreiro R \& Paveia H (2000) The Oenococcus oeni genome: Physical and genetic mapping of strain GM and comparison with the genome of a 'divergent' strain, PSU-1. Microbiology 146: 3195-3204.

Zhou JS, Shu Q, Rutherfurd KJ, Prasad J, Gopal PK \& Gill HS (2000a) Acute oral toxicity and bacterial translocation studies on potentially probiotic strains of lactic acid bacteria. Food Chem. Toxicol. 38: 153-61.

Zhou JS, Shu Q, Rutherfurd KJ, Prasad J, Birtles MJ, Gopal PK \& Gill HS (2000b) Safety assessment of potential probiotic lactic acid bacterial strains Lactobacillus rhamnosus HN001, Lb. acidophilus $\mathrm{HN} 017$, and Bifidobacterium lactis $\mathrm{HN} 019$ in BALB/c mice. Int. J. Food Microbiol. 56: 87-96.

Zhou JS, Gopal PK \& Gill HS (2001) Potential probiotic lactic acid bacteria Lactobacillus rhamnosus (HN001), Lactobacillus acidophilus (HN017) and Bifidobacterium lactis (HN019) do not degrade gastric mucin in vitro. Int. J. Food Microbiol. 63: 81-90.

Zuniga M, Pardo I \& Ferrer S (1996) Transposons Tn916 and Tn925 can transfer from Enterococcus faecalis to Leuconostoc oenos. FEMS Microbiol. Lett. 135: 179-185. 